This item was submitted to Loughborough's Research Repository by the author.

Items in Figshare are protected by copyright, with all rights reserved, unless otherwise indicated.

\title{
A systems thinking approach to stimulating and enhancing resource efficiency and circularity in households
}

PLEASE CITE THE PUBLISHED VERSION

https://doi.org/10.1016/j.jclepro.2020.123038

PUBLISHER

Elsevier

VERSION

AM (Accepted Manuscript)

\section{PUBLISHER STATEMENT}

This paper was accepted for publication in the journal Journal of Cleaner Production and the definitive published version is available at https://doi.org/10.1016/j.jclepro.2020.123038.

LICENCE

CC BY-NC-ND 4.0

\section{REPOSITORY RECORD}

Ng, Kok Siew, and Long Seng To. 2020. "A Systems Thinking Approach to Stimulating and Enhancing Resource Efficiency and Circularity in Households". Loughborough University.

https://hdl.handle.net/2134/12522872.v1. 


\section{Efficiency and Circularity in Households}

Kok Siew Ng ${ }^{\text {a,*, }}$ Long Seng $\mathrm{To}^{\mathrm{b}}$

${ }^{\text {a }}$ Department of Engineering Science, University of Oxford, Parks Road, Oxford OX1 3PJ, United Kingdom.

${ }^{\mathrm{b}}$ Geography \& Environment, School of Social Sciences \& Humanities, Loughborough University, Epinal Way, Loughborough, Leicestershire LE11 3TU, United Kingdom.

Abstract

Households are highly resource intensive in terms of energy consumption and waste generation, and resource utilisation and management in households has wider implications at the national level. This paper applies systems thinking using a circular economy approach at the household level for the first time. The approach takes into consideration energy supply and demand, waste management and resource recovery from waste in a single system. Combining energy and waste management analysis enables better understanding of the systems at household level and can address resource efficiency, fuel poverty and environmental issues more effectively at the national level. This study adopts the Systems Thinking Approach to Resource Recovery (STARR) framework to identify the potential improvements that can be made within the system. Three models of households on energy and waste management, including "waste-and-energy", "waste-to-energy" and "reduced consumption" models, are examined through assessments of economic, environmental and social dimensions. These models are further explored through different scenarios, by considering the adoption of renewable solar photovoltaic (PV) energy supply, increasing recycling rate, integrating energy from waste into household and reducing consumption of resources and waste generation. The scenario with the least environmental impact involves adopting a concerted approach through switching to solar PV, increasing recycling rate from 45 to $60 \%$ and sending $100 \%$ of residual waste into energy recovery (i.e. within the "waste-to-energy" model), with global warming potential (GWP) of $-1308 \mathrm{~kg} \mathrm{CO} 2^{-}$

Keywords: material flow analysis; circular economy; LCA; sustainability assessment; net zero; solar PV.

\footnotetext{
* Corresponding author. Email: kok.ng@eng.ox.ac.uk / kok_siew@hotmail.com; Tel: +44(0)7919 074975 (KS Ng)
} 
The UK has set an ambitious target to reach net zero in greenhouse gas (GHG) emissions by 2050 as

3 a significant step forward in response to the Paris Agreement 2015 and Intergovernmental Panel on

4 Climate Change (IPCC)'s goal of limiting the global average temperature rise to $1.5^{\circ} \mathrm{C}$ [1-3]. In the

5 UK, GHG emissions associated with the energy consumption from the residential sector is $65.9 \mathrm{Mt}$

$6 \mathrm{CO}_{2}$-equivalent, contributing $18 \%$ to the total $\mathrm{GHG}$ emissions of $364.1 \mathrm{Mt} \mathrm{CO}_{2}$-equivalent in the $\mathrm{UK}$

7 [4]. The increasing demands of energy and accompanying emissions will be a continuing concern to the nation unless significant reduction of GHG emissions takes place. Such stringent climate change mitigation targets can only be realised if deep decarbonisation (a concerted approach in transitioning to low-carbon economy through technological, socio-economic and policy pathways) is undertaken 11 in all sectors to achieve a $\mathrm{GHG}$ emission reduction of at least $40 \mathrm{Gt} \mathrm{CO}_{2}$-equivalent per annum [5]. 12 Deep decarbonisation requires revolutionary transformation in energy systems to achieve greater enhancement in energy efficiency and steep reduction in carbon intensity (i.e. $\mathrm{CO}_{2}$ emissions per unit of energy consumed or economic activity) [6]. Development and adoption of low-carbon technologies as well as changing of household consumption patterns and individual behaviours, together with the support of government policies are essential to achieving the net-zero target.

According to the latest UK Department for Environment, Food \& Rural Affairs (DEFRA)'s Digest of Waste and Resource Statistics, waste arising from households ("household waste" has been adopted consistently in this study to avoid confusion) was estimated to be 27.4 million tonnes a year in 2016 [7], corresponds to $2.76 \mathrm{~kg}$ /household-day or $1.14 \mathrm{~kg}$ /capita-day. The UK is obliged to meet a minimum recycling target of household waste of $50 \%$ by 2020 (Note: a revised target of $65 \%$ by 2030 has been proposed) according to the EU Waste Framework Directive (2008/98/EC) [8]. The UK recycling rate has reached $45 \%$ (excluding incineration bottom ash) in 2017 compared to $40.4 \%$ in 2010 [9], yet significant efforts are still required to meet the national/EU target. This also implies that significant value from waste has not been recovered and the concept of resource recovery from waste has not been well appreciated at household level.

Addressing the energy and waste issues at the household level independently without a holistic view of the problems and understanding of interdependencies between the systems may lead to missed opportunities for optimum use of resources. A systems thinking approach to circular economy needs to be established at household level, taking into consideration energy supply and demand, waste 31 management and resource recovery from waste in a single domain, which so far has not been 32 investigated. Systems thinking involves the consideration of multiple perspectives at its core, the 
1 interconnectedness of the different associated components constituted to a problem and multistakeholder collaboration to tackle complex problems and decision-making. Bosch et al. [10] proposed a systems thinking approach to addressing agriculture and natural resource management issues and investigated different case studies in Australia, Cambodia and the Philippines. Ng et al. [11] developed systems thinking methodologies and explored the sustainability impacts through synergistic utilisation of organic resources (i.e. food waste) from households and supermarkets. These studies demonstrated that improving the existing resource management practices requires different parts of a system (e.g. stakeholders, technological processes) to be integrated and the three main dimensions of sustainability (i.e. economic, environment and social dimensions) to be taken into account.

11 Conventionally and even until today, energy and waste management in household have been treated 12 as independent domains. In relation to research in the energy domain (activities or processes related 13 to consumption and production of energy), there are numerous optimisation studies [12-14] that focus 14 on identifying the best form of energy supply system for households through minimising operation cost and environmental emissions. Üçtuğ and Azapagic [15] examined the environmental impacts of adopting residential-scale integrated solar PV-battery system in households in Turkey and concluded that the resulting impact is 1.6-82.6 times lower than grid electricity. Golmohamadi et al. [16] studied the interaction between thermal-electrical characteristics of household appliances, the uncertainty in market retail prices for solar/wind electricity and the impact on power distribution network. A systems thinking approach was embedded in this study, however it has only explored the cost implication without considering environmental and social impacts. Most of the above studies have only considered cost and/or environmental implications. To the best of our knowledge, only the study by Vogt Gwerder et al. [17] has considered all three dimensions of sustainability. The authors have adopted the life cycle sustainability assessment (LCSA) and Multi-Criteria Decision Analysis (MCDA) approaches in examining the trade-offs between economic, environmental and social impacts of supplying the electricity and heating needs in two off-grid households in rural Portugal. For research related to waste domain (activities or processes related to generation and management of waste), Jeswani and Azapagic [18] conducted a detailed life cycle assessment (LCA) to compare the environmental sustainability of energy recovery scenarios including recovery of biogas from landfill or incineration, but this was conducted at national level. Jamasb and Nepal [19] studied the economic and environmental costs and benefits of waste-to-energy strategy and suggested that it plays a key role in both waste management and renewable energy policies in the UK. So far, studies on household waste minimisation and resource recovery are scarce. Overall, most of the studies are 
1 focused on either energy or waste domain but none of them have explored both energy and waste

2 domains using a holistic approach. Given that there is a lack of holistic understanding on resource management from a household perspective and the associated sustainability impacts on the whole system, there is an opportunity to address this gap of knowledge through examining both of these domains using a systems thinking approach, proposed in this paper.

In this study, a tri-lateral approach in systems thinking, presented in Figure 1 has been proposed and employed to identify the potential of energy efficiency and resource circularity enhancement in households. Circular economy is "an industrial system that is restorative or regenerative by intention and design" [20]. This suggests that waste can be used as resources and should be maintained in a loop in view of reducing virgin materials and energy and lessening the environmental burden associated with resource extraction, production, consumption and disposal [20]. Circularity in the present context implies that the linear resource production-consumption-disposal pattern is reconfigured into loop by returning the resources embedded in waste stream generated from households into useful product such as energy that can be consumed in a household. As a result, this would reduce the overall resource use and environmental impact. This research addresses United Nations Sustainable Development Goals (SDG) 7 on Affordable and Clean Energy and SDG 12 on Responsible Consumption and Production [21] in an integrated way.

The aim of this research is to explore the alternative strategies for improving resource utilisation in households while reducing costs and emissions. The following research questions will be answered in this study:

(a) What are the potential economic, environmental and social impacts on household if grid electricity supply is switched into on-site renewable electricity generation?

(b) What are the potential economic, environmental and social impacts on household if recycling rate is increased?

(c) What are the trade-offs on the economic, environmental and social dimensions if energy and waste domains are considered holistically within a single system from the household perspective?

The objectives of this study are to establish a new household resource management model by applying systems thinking approach and provide evidence-based recommendations for improving energy and waste management in household based on the potential impacts associated with economic, environmental and social dimensions. 


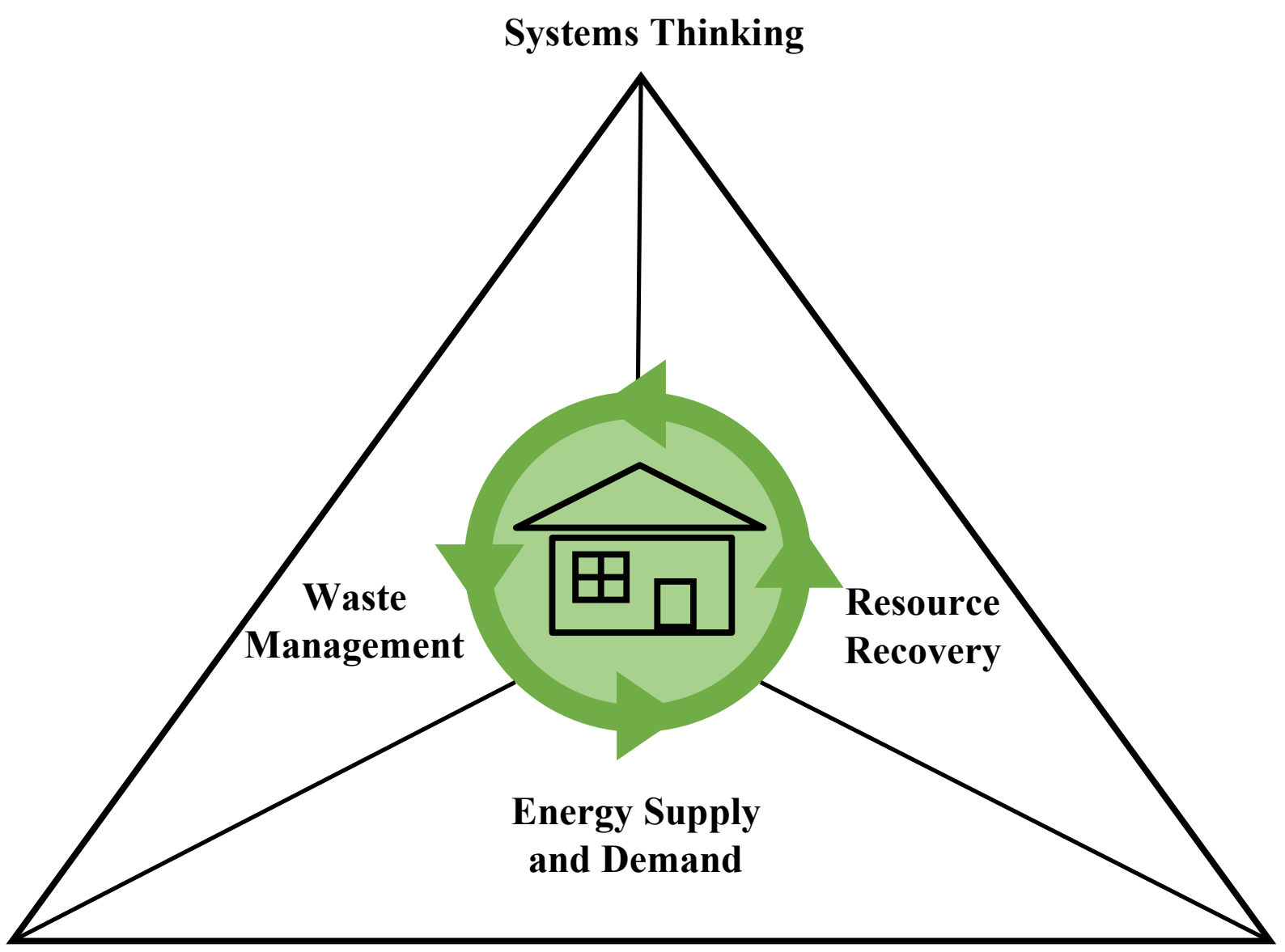

2 Figure 1: Conceptual diagram showing tri-lateral approach in systems thinking for enhancing energy efficiency and resource circularity in households.

\section{Methodology}

6 The Systems Thinking Approach to Resource Recovery (STARR) framework (Figure 2) proposed by

$7 \mathrm{Ng}$ et al. [11] has been adopted in this study to analyse and identify the potential improvement that 8 can be made by considering the energy and waste domains of household as a whole system. The 9 framework consists of: (1) system analysis; (2) scenario creation; and (3) sustainability assessment. 10 The principles and details of development of the STARR framework can be found in [11]. The 11 original STARR framework was developed to address waste management only and thus has been modified to suit the present context of combining both energy and waste domains.

13 System analysis: Material flow analysis [22], a systematic tool for the examination of the quantity 14 (i.e. level of energy consumption / waste generation) and quality (i.e. waste composition) of the 15 resources within the designated system boundary, has been conducted using Sankey diagrams for 16 both energy and waste domains. The main implications that can be derived from the material flow 
1 analysis are: (i) the source of energy supply (source analysis); (ii) the availability of waste for resource recovery from different categories of waste streams (source analysis); (iii) the level of energy consumption (sink analysis) and (iv) the flows of waste to different treatment/disposal routes that

4 determine the maximum resource recovery potential (sink analysis). The system analysis of resources

5 enables pragmatic scenarios to be created and further supports informed decision-making.

6 Scenario creation: Scenarios have been developed to explore business-as-usual system as well as 7 alternative systems by considering (i) source of energy supply; (ii) recycling rate; and (iii) resource 8 consumption. For the business-as-usual scenario, energy demand in household is supplied through 9 grid electricity while the most recent household recycling rate (excluding incineration bottom ash) in 10 the UK (2017) has been adopted. This will be discussed in detailed in section 3.5. Alternative systems 11 include (i) "waste-and-energy" model where improvements are made independently on individual 12 domains of energy and waste in household (i.e. without the perception that energy can be recovered 13 from waste); (ii) "waste-to-energy" model where a holistic approach is used to improve the energy 14 and waste domains in households (i.e. with the perception that energy can be recovered from waste); 15 and (iii) "reduced consumption" model where energy consumption and waste generation from 16 household are reduced. Systems thinking has been embedded within "waste-to-energy" scenario by 17 considering circular economy strategy [20] and design for sustainability principles [23]. The objective 18 is to promote efficient resource utilisation and waste diversion from landfill through enhancing 19 recycling and recovery practices and thus improving the resource efficiency of the system. 


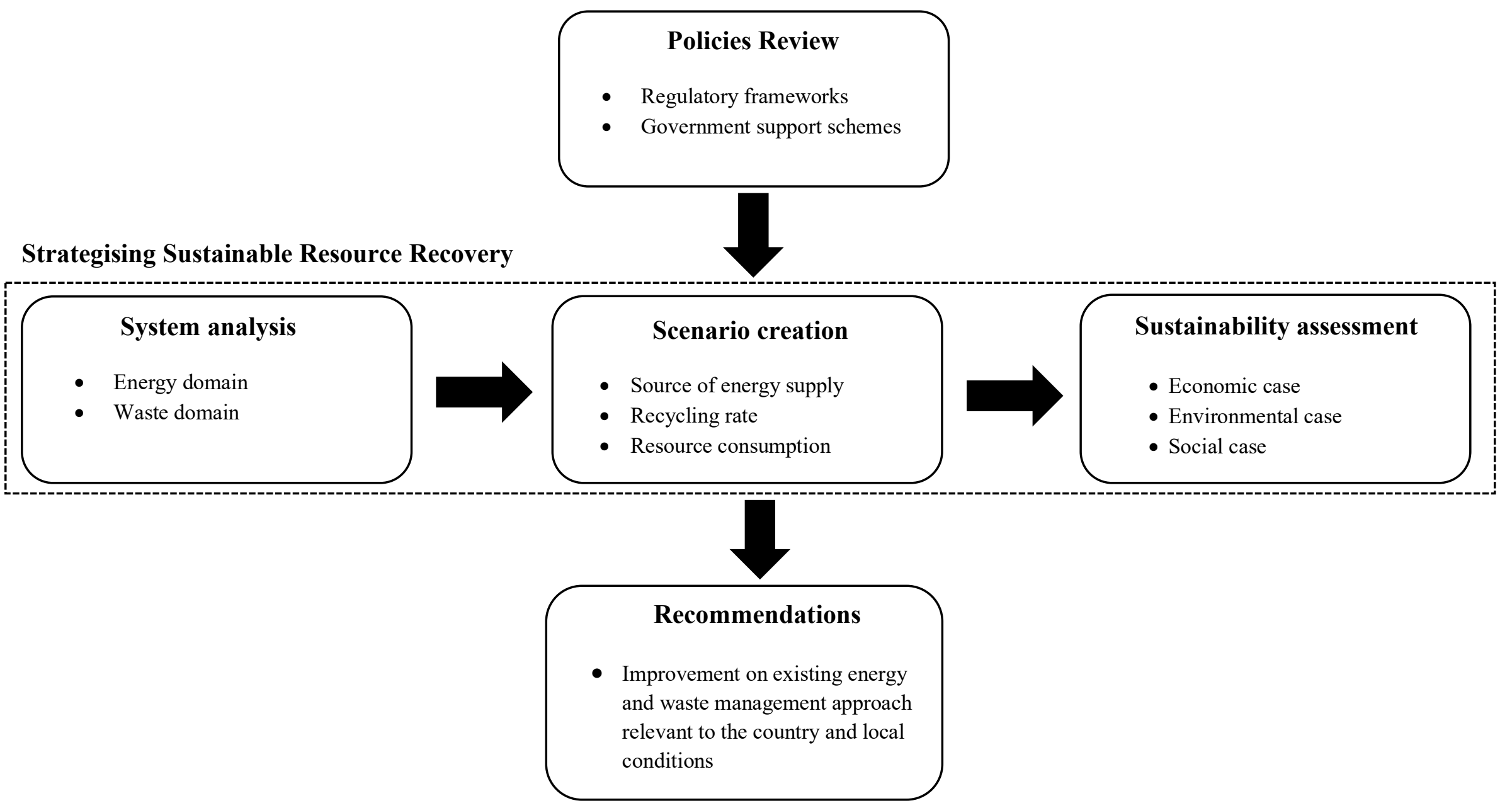

Figure 2: Framework for systems thinking approach to resource recovery (STARR) [11]. 
1 Sustainability assessment: The economic, environmental and social impacts of each scenario have 2 been examined using sustainability assessment [24-26]. The assessment enables us to make sound decisions and assertions of what action should be taken in order to make the system more sustainable.

4 The economic impact of the scenarios was assessed using cost-benefit analysis in this study. This 5 included the evaluation of (i) annual electricity cost per household; (ii) indicative value of waste per 6 household per year; and (iii) the annual cost saving potential per household (inclusive of fiscal 7 incentives).

8 The environmental impact was assessed using environmental LCA, which systematically quantifies 9 the resource use and emissions resulting from various activities and processes considered within the 10 system boundary. In this study, LCA has been conducted according to the ISO principles and 11 framework laid out in ISO 14040:2006 which comprises four evaluation phases: (i) goal and scope definition; (ii) inventory analysis; (iii) impact assessment and (iv) interpretation [27]. SimaPro 9.0 software has been employed to conduct the LCA for energy consumption and waste generation scenarios. This study considers a comprehensive range of impact categories which goes beyond the standard carbon footprint assessment specified in PAS 2050 [28] and GHG Protocol [29].

(i) Goal and scope definition

- Goal statement: The goal of this LCA study is to determine the trade-offs in environmental impacts if a household is to adopt a "waste-and-energy", "wasteto-energy" or "reduced consumption" model.

- Functional unit for energy consumption scenario: Production of $1 \mathrm{kWh}$ of electricity

- Functional unit for waste generation scenario: Treatment of $1 \mathrm{~kg}$ of household waste

- System boundary: The boundary of study includes the generation of grid electricity or electricity generation from solar PV, waste treatment/disposal/recovery/transportation, where household is placed at the core. Figure 3 illustrates the system boundary and life cycle stages of the energy and waste domains in households examined in this study.

- Allocation method: product substitution. This method implies that the environmental burdens are allocated proportionally to specific processes.

- Assumptions: The assessment assumes steady-state energy consumption level and waste generation using an average value per household (i.e. total national energy 
consumption/waste generation divided by total number of households in the country). The number of occupants, type and size of household, appliances, nature of activities in the household or associated with household have not been considered due to high level of variability across each individual household.

\section{(ii) Inventory analysis}

- The inventory data from Ecoinvent 3.5 database embedded in SimaPro 9.0 has been employed.

\section{(iii) Impact assessment}

- CML-IA baseline V3.05 / EU25 has been selected because it is widely adopted in many LCA studies for mid-point impact assessment. The impact categories under consideration include: abiotic depletion potential (ADP); global warming potential (GWP); ozone depletion potential (ODP); human toxicity potential (HTP); freshwater aquatic ecotoxicity potential (FAEP); marine aquatic ecotoxicity potential (MAEP); terrestrial ecotoxicity potential (TEP); photochemical oxidant creation potential (POCP); acidification potential (AP); and eutrophication potential (EP).

- Damage impact to human health has been examined using ReCiPe 2016 Endpoint using the default "Hierarchical" method, considering the timeframe applied in most common policy principles [30]. This impact category arising from multiple causes such as climate change, exposure to toxic chemicals and particulate matters, and ozone layer depletion has been quantified using the metric of DisabilityAdjusted Life Year (DALY). DALY represents the years of life lost due to a combination of premature death and disease.

\section{(iv) Interpretation}

- The results from impact assessment have been presented in detailed table format and have further been refined to presentable format using bar charts in view of analysing the results across different scenarios more effectively and drawing conclusions.

- Dominance analysis has been performed for each impact category to examine the magnitude of impact for each scenario. 
2 The social impact of each scenario was assessed by considering public acceptance and participation

3 which influences the transformation in technology uptake and resource management practices. Public

4 acceptance and participation is the key consideration in implementation of new household resource 5 management models [24, 31]. In this context, the contributing factors for increasing the uptake of 6 renewable energy technology and recycling rate have been discussed.

\section{Sources of data}

9 Energy consumption: For energy-related information, the present study has adopted secondary data 10 from the UK Department for Business, Energy and Industrial Strategy (BEIS). BEIS published data 11 on annual electricity consumption based on household type and appliance as well as domestic energy 12 prices [32-34]. Ofgem also provides information on Feed-in Tariff (FiT) rates and representative 13 estimated value of household electricity consumption that has been widely adopted in the energy 14 retail market $[35,36]$ (Note: the analysis was conducted in 2019 before FiT was phased out). The cost 15 data for solar PV has been obtained from BEIS [37].

16 Waste generation: Waste data including flow and composition have been obtained from the Digest of Waste and Resource Statistics published by DEFRA [7]. This is a secondary source of data and contains most of the required information for different waste streams. However, the compositional

19 data for residual waste stream has not been found from DEFRA's publication and hence the data from 20 VALORGAS (an EU FP7 project) report has been adopted [38]. The average prices paid for collected 21 recyclable materials such as metals, glass, papers and cards and plastics have been obtained from 22 Letsrecycle.com [39]. The waste management costs embedded in the council tax bill has been estimated based on the information published by Oxfordshire County Council [40]. 


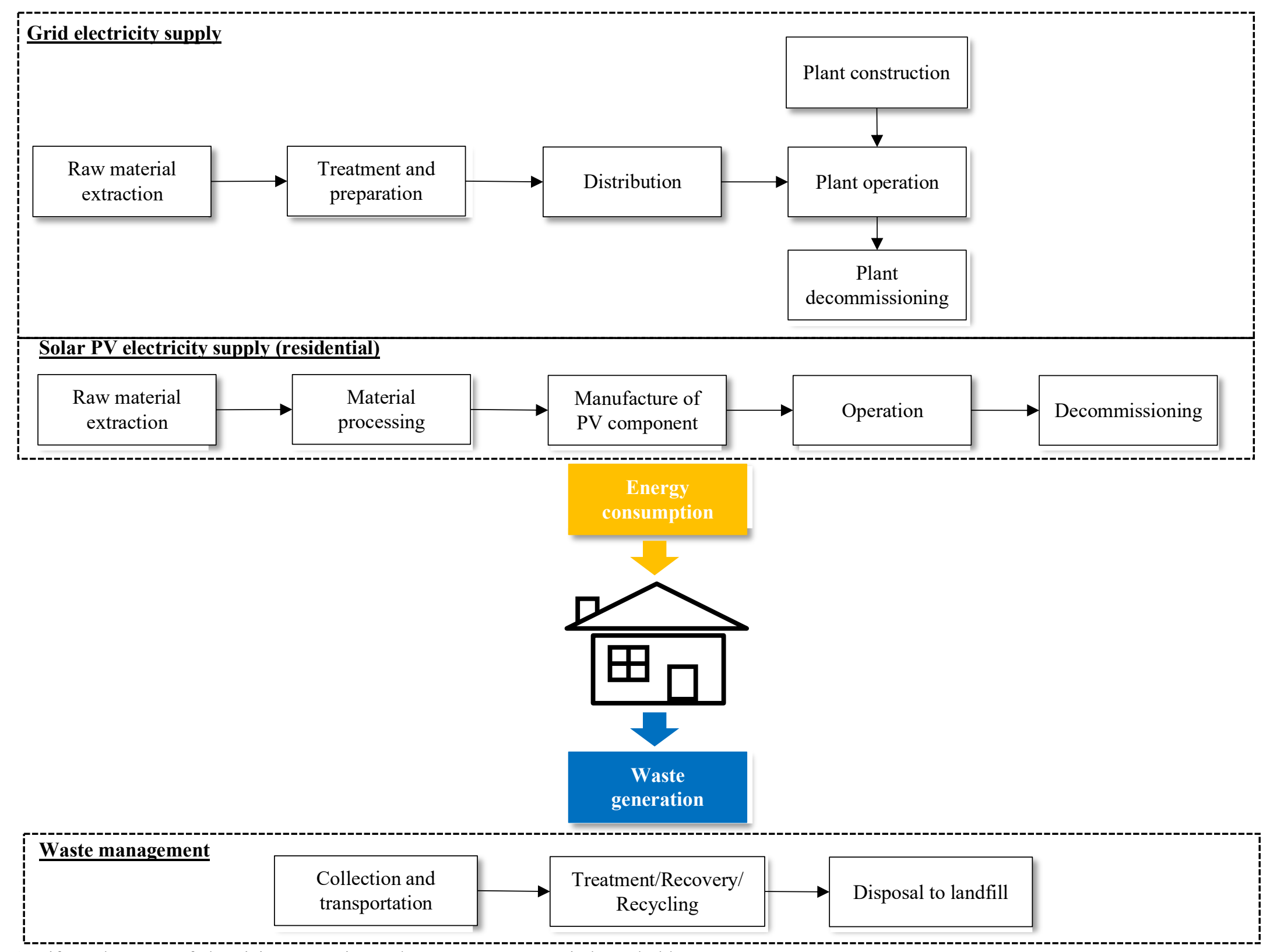

Figure 3: Life cycle stages of electricity generation and waste management in household. 


\subsection{Policy review}

4 The National Renewable Energy Action Plan for the United Kingdom has set out the targets of delivering 15\% of energy from renewables by 2020 [41], guided by the Renewable Energy Directive 2009/28/EC [42]. During the transition period of exiting the EU, the UK has produced a draft integrated National Energy and Climate Plan (NECP), however, the UK contribution towards meeting the 2030 targets for renewable energy and energy efficiency remain unspecified [43, 44]. In the dimension of decarbonisation, the UK is legally bound to Climate Change Act 2008 to meet the netzero target by 2050 [1].

The UK waste management policies are influenced by the EU Waste Framework Directive (2008/98/EC) [8] which deals with general mixed waste. Under the Directive, the UK is required to meet a minimum 50\% recycling target of household waste by 2020 (Note: a revised target of $65 \%$ by 2030 has been proposed) and follow the waste management hierarchy of prevention, reuse, recycling, recovery and disposal [8]. The waste hierarchy has been incorporated into the UK legal framework through the Waste (England and Wales) Regulations 2011, the Waste Regulations (Northern Ireland) 2011, and the Waste (Scotland) Regulations 2012. The UK is also obliged to meet the reduction targets of biodegradable municipal solid waste going to landfill of $75 \%$ by $2000,50 \%$ by $2013,35 \%$ by 2020 and $10 \%$ by 2030 as set out in the EU Landfill Directive (Directive 1999/31/EC) [45],

The application of systems thinking approach in addressing energy and waste management from a household perspective is illustrated in Figure 4. In the present context, the household is represented by two resource domains: energy and waste. It has been assumed that there is no interaction between the energy and waste domains in the household, i.e. adjusting the level of energy consumption has no effect on the amount of waste generation and vice versa. The energy demand in household can be 
1 waste through Energy-from-Waste (EfW) facilities which includes combined heat and power (CHP)

2 production. The source of energy supply and fuel determine the degree of environmental impact resulting from the system. The level of household energy consumption can be correlated with the type

4 of appliance and the associated cost of household electricity has been estimated and detailed in section

5 3.3. Waste generation from household includes residual waste, dry recycling and organic waste

6 stream. Residual waste is sent to either landfill or incineration; dry recycling is sent to recycling centre;

7 and organic waste such as source-segregated food waste is sent to anaerobic digestion (AD) where

8 biogas and fertiliser are produced. The details of waste composition and the associated indicative

9 value has been estimated and discussed in section 3.3. Different resource utilisation models have been

10 encapsulated in a range of scenarios, presented in section 3.5.

11 Material flow analysis has been performed as shown in Figure 5. The energy supply is correlated with 12 different appliance in household which has been categorised into kitchen appliance, general utility, 13 entertainment and ICT, and miscellaneous. Kitchen appliance contributes one-third of the total energy 14 consumption in household and the remaining categories of appliance carry almost equal share of 15 energy consumption. Details of the energy consumption based on type of appliance are presented in 16 section 3.4. On the other hand, waste generation from household has been classified into five different 17 categories: food waste, paper and card, glass, metals and plastics. These waste materials are 18 discharged into different waste streams, namely residual waste, dry recycling and organic waste. It 19 can be seen that food waste contribute $43 \%$ of the household waste, of which only less than half has 20 been segregated. The material flow analysis also indicates that paper and card distribute evenly 21 between residual waste and dry recycling streams; while $60-70 \%$ of glass and metals sent for 22 recycling; and $80 \%$ of plastics ended up in residual waste stream. Details of the waste composition 23 and assumptions are discussed in section 3.4. 


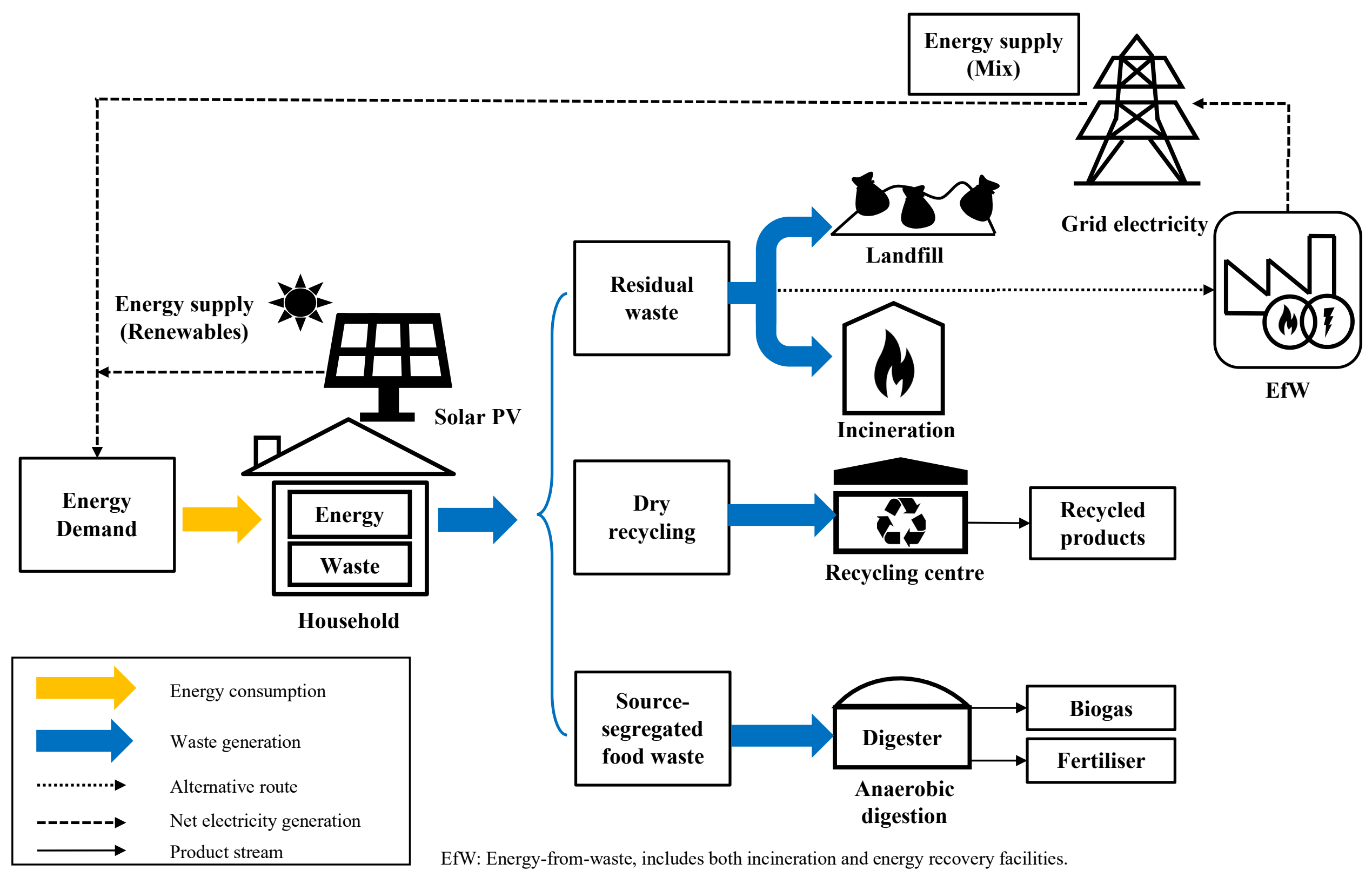

Figure 4: Household systems thinking mind map. 


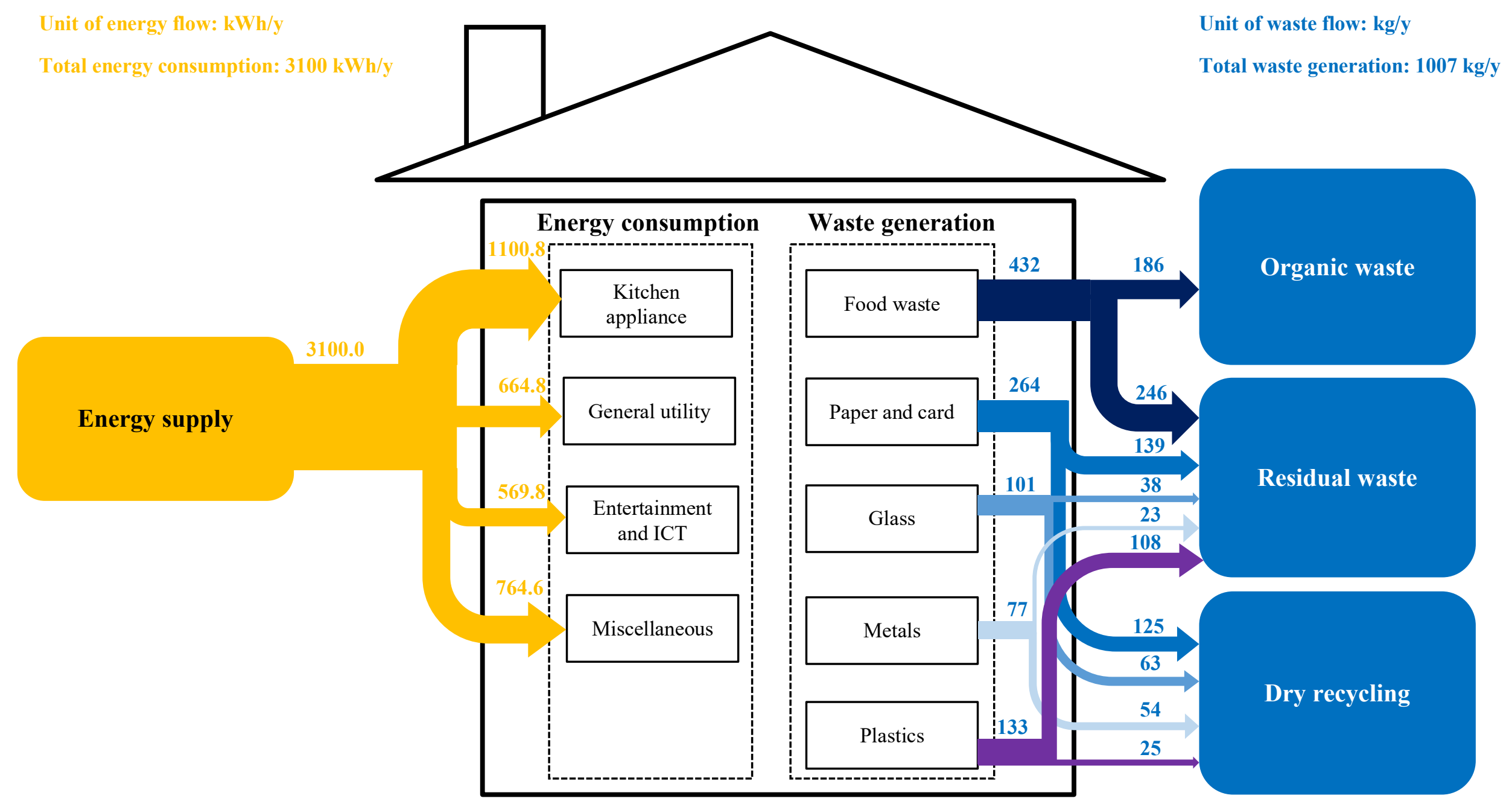

Figure 5: Material flow analysis showing energy consumption and waste generation per household basis. 
2 Table 1 provides different estimation of annual UK household electricity consumption and cost based 3 on household types, appliances and consumption data. The electricity cost has been estimated using 4 a unit electricity price of 18 pence/kWh [34]. The summary in Table 1 demonstrates a range of values of annual electricity consumption between $1900 \mathrm{kWh}$ and $4600 \mathrm{kWh}$ per household which associated with annual electricity cost between $£ 342$ and $£ 828$ per household. The variation in the estimated values are attributed to the data collection and monitoring techniques, household type and occupancy and various consumption patterns. The medium typical domestic consumption value (TDCV) value of $3100 \mathrm{kWh}$ per household estimated by Ofgem has been taken as the basis for subsequent analysis. Table 1: Range of estimated annual electricity consumption and cost per household in the UK based on different basis of estimation $[32,33,35]$.

\begin{tabular}{|c|c|c|c|c|c|}
\hline $\begin{array}{c}\text { Basis of } \\
\text { estimation }\end{array}$ & Data supplier & $\begin{array}{r}\text { Annua } \\
\text { consu } \\
\text { househ }\end{array}$ & $\begin{array}{l}\text { tricity } \\
\text { on per } \\
\text { xWh/y) }\end{array}$ & $\begin{array}{c}\text { Annual } \\
\text { electricity cost } \\
\text { per household } \\
(\mathfrak{f} / \mathbf{y})\end{array}$ & Note \\
\hline \multirow{3}{*}{ Household type (i) } & \multirow{3}{*}{ DECC (now BEIS) } & Low & 3083 & 554.94 & \multirow{3}{*}{$\begin{array}{l}\text { Data collected from } \\
250 \text { households. }\end{array}$} \\
\hline & & Average & 3567 & 642.06 & \\
\hline & & High & 4399 & 791.82 & \\
\hline Appliance (ii) & DECC (now BEIS) & Average & 4041.5 & 727.46 & $\begin{array}{l}\text { Data collected from } \\
250 \text { households. }\end{array}$ \\
\hline \multirow[b]{3}{*}{ Consumption data } & \multirow[b]{3}{*}{ Ofgem } & Low & 1900 & 342.00 & \multirow{3}{*}{$\begin{array}{l}\text { Typical domestic } \\
\text { consumption value } \\
\text { (TDCV) (iii). } \\
\text { Electricity: Profile } \\
\text { Class 1. Data collected } \\
\text { based on domestic } \\
\text { credit meters. }\end{array}$} \\
\hline & & Medium & 3100 & 558.00 & \\
\hline & & High & 4600 & 828.00 & \\
\hline
\end{tabular}

13 (i) See Supplementary Materials: Table A.1 for detailed information of annual electricity consumption for each household type.

(ii) See Table 2 for the breakdown of electricity use for each appliance.

(iii) TDCV is the representative estimated value used in the energy retail market to facilitate communication between suppliers and consumers.

A previous study by BEIS has estimated that an average daily electricity usage of $11.1 \mathrm{kWh}$, equivalent to $4041.5 \mathrm{kWh}$ annual usage are required for a household in the UK. Table 2 presents a breakdown of the electricity use by appliances, together with the associated costs and GWP (equivalent to GHG or carbon footprint). The results show that kitchen appliances such as refrigerators, cooking stoves, microwaves, ovens, washing machines and dishwasher contribute onethird of the total household electricity use, while audio visual (13.3\%) and lighting (10.9\%) are also among the largest contributors to the household electricity use. 
Table 2: UK household average daily and annual electricity use by appliance.

\begin{tabular}{|c|c|c|c|c|c|c|}
\hline Appliance ${ }^{(i)}$ & $\begin{array}{l}\text { Average daily } \\
\text { electricity use per } \\
\text { household }^{\text {(ii) }} \\
\text { (kWh) }\end{array}$ & $\begin{array}{l}\text { Annual electricity } \\
\text { use per household } \\
\text { (kWh) }\end{array}$ & $\begin{array}{l}\text { Normalised annual } \\
\text { electricity use per } \\
\text { household (kWh) } \\
\text { based on } 3100 \mathrm{kWh}\end{array}$ & $\begin{array}{c}\% \\
\text { contribution } \\
\text { to total } \\
\text { electricity use }\end{array}$ & $\begin{array}{c}\text { Cost breakdown } \\
\text { based on annual } \\
\text { consumption of } \\
3100 \mathrm{kWh}(\mathfrak{f} / \mathrm{y})^{(\mathrm{iv})}\end{array}$ & $\begin{array}{c}\text { GWP } \\
\text { (kg CO} \\
\text { equivalent) } \\
(v)\end{array}$ \\
\hline \multicolumn{7}{|l|}{ Kitchen appliance } \\
\hline Cold appliance & 1.55 & 567.2 & 435.1 & 14.0 & 78.3 & 362.0 \\
\hline Cooking & 1.21 & 440.3 & 337.7 & 10.9 & 60.8 & 281.0 \\
\hline Washing/drying/dishwasher & 1.17 & 427.6 & 328.0 & 10.6 & 59.0 & 272.9 \\
\hline Sub-total & 3.93 & 1435.1 & 1100.8 & 35.5 & 198.1 & 916.0 \\
\hline \multicolumn{7}{|l|}{ General utility } \\
\hline Lighting & 1.27 & 464.7 & 356.5 & 11.5 & 64.2 & 296.6 \\
\hline Water heating & 0.23 & 83.4 & 64.0 & 2.1 & 11.5 & 53.3 \\
\hline Heating & 0.57 & 207.9 & 159.5 & 5.1 & 28.7 & 132.7 \\
\hline Showers & 0.30 & 110.5 & 84.8 & 2.7 & 15.3 & 70.5 \\
\hline Sub-total & 2.37 & 866.6 & 664.7 & 21.4 & 119.7 & 553.1 \\
\hline \multicolumn{7}{|l|}{ Entertainment and ICT } \\
\hline Audio-visual & 1.47 & 536.5 & 411.5 & 13.3 & 74.1 & 342.4 \\
\hline $\mathrm{ICT}^{\text {(iii) }}$ & 0.57 & 206.4 & 158.3 & 5.1 & 28.5 & 131.7 \\
\hline Sub-total & 2.04 & 742.9 & 569.8 & 18.4 & 102.6 & 474.1 \\
\hline \multicolumn{7}{|l|}{ Miscellaneous } \\
\hline Other & 0.47 & 173.0 & 132.7 & 4.3 & 23.9 & 110.4 \\
\hline Unknown & 2.26 & 823.8 & 631.9 & 20.4 & 113.7 & 525.8 \\
\hline Sub-total & 2.73 & 996.9 & 764.6 & 24.7 & 137.6 & 636.2 \\
\hline Total & 11.07 & 4041.5 & 3100.0 & 100.0 & 558.0 & 2579.5 \\
\hline
\end{tabular}

Notes:

(i) Cold appliance, cooking and washing/drying/dishwasher have been categorised under "kitchen appliance"; lighting, water heating, heating and showers have been categorised under "general utility"; audio-visual and ICT have been categorised under "Entertainment and ICT"; and other and unknown have been treated as "miscellaneous" in the material flow diagram shown in Figure 5.

(ii) The data was obtained from 250 households in year 2010/11, monitored over 12 months using meter on total electricity use and most appliances [32, 33].

(iii) ICT: Information and Communication Technology.

(iv) Cost has been estimated based on unit price of electricity of 18 pence/kWh [34].

(v) GWP for producing $1 \mathrm{kWh}$ of electricity is $0.8321 \mathrm{~kg} \mathrm{CO}_{2}$-equivalent using CML method. 
1 Table 3 summarises the installed cost and financial benefits by adopting solar PV of $4 \mathrm{~kW}$ installed capacity for a household which requires $3100 \mathrm{kWh}$ of annual electricity supply. The PV of the specified capacity generates approximately $3400 \mathrm{kWh}$ of electricity. By assuming that $100 \%$ of the annual electricity demand in household has been supplied from PV (91\% usage), while $300 \mathrm{kWh}$ is exported to the grid annually, this gives a total saving/income of $£ 703$ per year (including avoided cost for grid electricity and income generated from FiT) with a payback period of 10.6 years. The UK used FiTs to promote renewable electricity generation technologies, including solar PV. FiT consists of generation tariff and export tariff and these have been accounted for based on the installed capacity of the facility. These are the incentives offered to household owners who generates their own electricity and exports the surplus electricity to the grid. However, it should be noted that FiT scheme in the UK closed on $31^{\text {st }}$ March 2019 and may be replaced by Smart Export Guarantee (SEG) scheme.

12 This suggests that household may only be benefited from the avoided cost of electricity bill and thus 13 longer payback period of 13.4 years is expected.

Table 3: Cost associated with PV installation and financial benefits for household.

\begin{tabular}{|l|c|c|}
\hline \multicolumn{1}{|c|}{ Specification } & Unit & Value \\
\hline Basis & & \\
\hline PV installed capacity & $\mathrm{kW}$ & $4^{\text {(i) }}$ \\
\hline Annual electricity production from PV & $\mathrm{kWh} / \mathrm{y}$ & $3400^{\text {(ii) }}$ \\
\hline & & \\
\hline Cost & & \\
\hline Total cost of PV & $£$ & $7468^{\text {(iii) }}$ \\
\hline & & \\
\hline Financial benefit & & \\
\hline Saving on electricity bill at (avoided cost) & $£ / y$ & $558^{\text {(iv) }}$ \\
\hline FiT, generation (income) & $£ / y$ & $128.86^{\text {(v) }}$ \\
\hline FiT, export (income) & $£ / y$ & $16.14^{\text {(v) }}$ \\
\hline Saving/income for 1 year & $£ / y$ & 703 \\
\hline Saving/income over 20 years & $£$ & 14060 \\
\hline & & \\
\hline KPI & & \\
\hline Payback time, with FiT & years & $10.6^{\text {(vi) }}$ \\
\hline Payback time, without FiT & years & 13.4 \\
\hline
\end{tabular}

17 (i) Assuming for 1 household; roof space $=28 \mathrm{~m}^{2} ; 16 \times 250 \mathrm{~m}^{2}$ solar panels [48].

18 (ii) Estimation based on $850 \mathrm{kWh}$ electricity generation per $\mathrm{kW}$ installed capacity [49].

19 (iii) Calculated based on $£ 1867$ per kW installed for size band $0-4 \mathrm{~kW}$ (mean; March 2019). Cost includes "Cost of solar 20 photovoltaic generation equipment, plus direct costs of fixing panels to roof/ground mount, any performance displays and 21 connecting to electricity supply, including VAT but excluding (a) the cost of any extended warranty; and (b) the cost of any other materials, works or other items whatsoever (such as, but not limited to, any cost of general rewiring at a property 
or tracker systems). It should be noted that the data are therefore wholesale costs and do not represent the cost that the householder has paid for the installation.'[37]

(iv) Based on an annual electricity consumption of $3100 \mathrm{kWh}$ in household and unit electricity price of 18 pence/kWh. See 4 Table 1.

(v) FiT generation $=3.79$ pence $/ \mathrm{kWh}$; FiT export $=5.38$ pence $/ \mathrm{kWh}[36]$.

(vi) Payback period is calculated by dividing the cost of PV by annual saving/income.

\subsection{Household waste management}

9 Household waste in the UK is managed by the local authorities or councils. Council tax bill 10 incorporates the proportion of spending on waste collection, recycling and disposal and is fixed for a 11 specific band of household which is dictated by its property value. Table 4 exemplifies the council tax expenditure on waste management set by Oxfordshire County Council for year 2019-2020 [40].

13 It has been estimated that each household owner is responsible for an average of $£ 1461$ of council tax bill per year of which $£ 87.7$ will be used for waste management purposes.

Table 4: Estimation of the proportion of council tax bill relevant to waste collection, recycling and disposal.

\begin{tabular}{|c|c|c|}
\hline $\begin{array}{l}\text { Specification } \\
\end{array}$ & Value & Unit \\
\hline Council spending (Oxfordshire County Council) & $600.3^{\text {(i) }}$ & million $£ / y$ \\
\hline Percentage of total expenditure on waste disposal and recycling & $6^{(\mathrm{i})}$ & $\%$ \\
\hline Expenditure on waste disposal and recycling (A) & 36.0 & million $£ / y$ \\
\hline Amount of household waste & $285000^{(\mathrm{i})}$ & tonnes \\
\hline Council spending per tonne of waste & 2106.3 & $£ / t$ \\
\hline Percentage contribution of council tax towards council expenditure (B) & $63^{(i)}$ & $\%$ \\
\hline Contribution of council tax towards council expenditure & 378.2 & million $£ / y$ \\
\hline Number of households (C) & $258855^{\text {(ii) }}$ & households \\
\hline Average council tax contribution per household & 1461.0 & $£ / y$ \\
\hline Contribution of council tax per household towards waste disposal and recycling (D) & $87.7^{\text {(iii) }}$ & $£ / \mathbf{y}$ \\
\hline
\end{tabular}

17 Notes:

18 (i) Values obtained from Oxfordshire County Council [40].

19 (ii) Based on 2011 Census data [50].

$20 \quad$ (iii) $\mathrm{D}=(\mathrm{A} \times \mathrm{B}) / \mathrm{C}$

21 Household waste in the UK is categorised into residual waste, dry recycling, other organics and 22 separately collected food waste based on the DEFRA's WasteDataFlow definition [7]. Residual waste 23 consists of the waste from black refuse sacks (regular household collection), household civic amenity 24 waste, bulky waste, and rejects from recycling. Dry recycling refers to materials that can be processed 25 in recycling facilities such as paper and card, glass, plastic, waste electrical and electronic equipment 
1 (WEEE) and scrap metals. Other organics comprises green garden waste, food waste and other compostable waste. In England, residual waste contribute 55\% (12.5 million tonnes in year 2016) to the total household waste; followed by dry recycling (6 million tonnes/year, 26.5\%); separately collected food waste (3.8 million tonnes/year, 16.8\%) and other organics $(0.4$ million tonnes/year, $1.7 \%)$.

Household waste, in the present context, has been categorised into residual waste, dry recycling and organic waste streams. A representative set of composition has been adopted in this study as presented in Table 5 and it has been assumed that:

Detailed composition of residual waste and dry recycling streams from the original dataset can be found in Supplementary Materials: Table A.3 and Table A.4, respectively. Table 5 presents the compositions of each representative component in different waste stream from household, the waste flow in annual and daily bases at the national UK and household levels and also the indicative value of the waste streams. The results which reflect the current situation in the UK shows a recycling rate of household waste of $45 \%$ has been achieved [7, 9], where dry recycling and organic waste streams are considered as recyclable fractions while residual waste is considered as non-recyclable fraction. Recycling rate is defined as the recycled amount of household waste divided by total amount of household waste excluding certain waste categories such as street cleaning/sweeping, gully emptying, separately collected healthcare waste, soil, rubble, plasterboard and asbestos waste [9, 46]. It should be noted that incineration bottom metals have now been included in the calculation of recycling rate.

The indicative values of each component in the waste stream have been estimated using the average prices paid for collected materials: paper and card (36£/t based on mixed paper price, November 2018); glass (11 £/t based on mixed glass price, October 2018); metals (947.5£/t based on aluminium cans price, October 2018) and plastics (15 £/t based on mixed plastic bottles price, October 2018)

31 [39]. It has been assumed that food waste has zero price in the market. As can be seen in Table 5, the 32 value of household waste is dominated by the dry recycling stream $(63 \%$ of total value, 56.8 
$1 £$ /household-year or $0.16 £$ /household-day), mainly attributed to the high market price for metals. In

2 other words, the analysis also implies that $28.9 £$ /household-year or $0.08 £$ /household-day has been

3 lost. Theoretically speaking, if all the materials from the residual waste stream can be recovered, this

4 means that additional revenue of $28.9 £$ /household-year $\times 27.2$ million households $=786$ million

$5 £ /$ year for the whole UK can be created. These results suggests that a higher recycling rate, i.e. shifting

6 of materials from residual waste to dry recycling stream is urgently needed to avoid further economic 7 loss.

8 Figure 6 shows that a 5\% increase in recycling rate can give 3\% increase in value of waste from 9 household per year, which is equivalent to 74 million $£ /$ year of value generation at national level. The 10 total value of household waste can potentially be enhanced from $85.7 £$ /household-year (2331 million $11 £ /$ year at the UK level) at $45 \%$ recycling rate to $93.8 £ /$ household-year (2551 million $£ /$ year at the 12 UK level) at $60 \%$ recycling rate. The economic driver for promoting more recycling practices at 13 household is thus significant. It should also be noted that food waste has a zero value as assumed in 14 this analysis which is currently under-valued in the market.

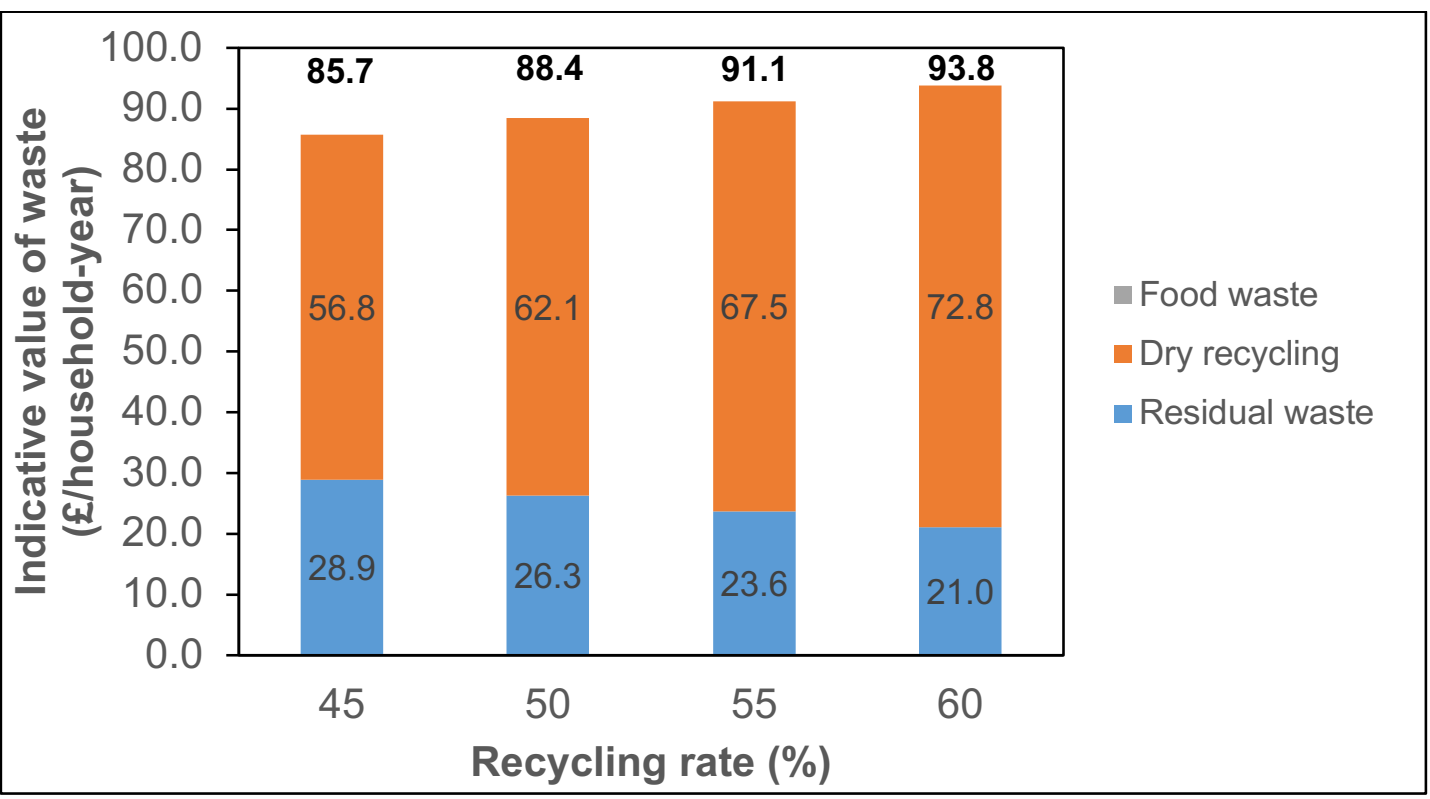

Figure 6: Indicative value of waste from households in response to the increase in recycling rate. 
Table 5: Flow, composition and value of waste from households in the UK.

\begin{tabular}{|c|c|c|c|c|c|c|c|c|}
\hline \multirow{2}{*}{ Total household waste } & 27.4 & \multicolumn{7}{|c|}{ million tonnes/year ${ }^{(\mathrm{i})}$} \\
\hline & 75068.5 & \multicolumn{7}{|c|}{ tonnes/day } \\
\hline Number of households in the UK & 27.2 & \multicolumn{7}{|l|}{ million ${ }^{(i i)}$} \\
\hline \multirow{2}{*}{ Average waste generation per household } & 1.01 & \multicolumn{7}{|c|}{ tonnes/household-year (iii) } \\
\hline & 2.76 & \multicolumn{7}{|c|}{$\mathrm{kg} /$ household-day } \\
\hline \multicolumn{9}{|l|}{$\underline{B r e a k d o w n}$ of household waste stream $^{\text {(iv) }}$} \\
\hline Total residual waste & 15.1 & \multicolumn{7}{|c|}{ million tonnes/year } \\
\hline Total dry recycling & 7.3 & \multicolumn{7}{|c|}{ million tonnes/year } \\
\hline Total organic waste & 5.1 & \multicolumn{7}{|c|}{ million tonnes/year } \\
\hline \multirow{2}{*}{ Category } & $\begin{array}{c}\text { Composition } \\
(\mathrm{v})\end{array}$ & $\begin{array}{l}\text { Normalised } \\
\text { composition }\end{array}$ & \multicolumn{2}{|c|}{ Waste flow (annual basis) } & \multicolumn{2}{|c|}{ Waste flow (daily basis) } & \multicolumn{2}{|c|}{ Indicative value of waste } \\
\hline & $\%$ & $\%$ & $\begin{array}{c}\text { million } \\
\text { tonnes/year }\end{array}$ & $\begin{array}{c}\text { tonnes/household- } \\
\text { year }\end{array}$ & tonnes/day & $\begin{array}{c}\text { kg/household- } \\
\text { day }\end{array}$ & $\begin{array}{c}\text { f/household- } \\
\text { day }\end{array}$ & $\begin{array}{c}\text { f/household- } \\
\text { year }\end{array}$ \\
\hline \multicolumn{9}{|l|}{ Residual waste } \\
\hline Food waste & 32.0 & 44.4 & 6.7 & 0.246 & 18352.5 & 0.675 & 0.000 & 0.00 \\
\hline Paper and card & 18.0 & 25.0 & 3.8 & 0.139 & 10323.3 & 0.380 & 0.014 & 4.99 \\
\hline Glass & 5.0 & 6.9 & 1.0 & 0.038 & 2867.6 & 0.105 & 0.001 & 0.42 \\
\hline Metals & 3.0 & 4.2 & 0.6 & 0.023 & 1720.5 & 0.063 & 0.060 & 21.88 \\
\hline Plastics & 14.0 & 19.4 & 2.9 & 0.108 & 8029.2 & 0.295 & 0.004 & 1.62 \\
\hline Sub-Total & 72.0 & 100.0 & 15.1 & 0.554 & 41293.2 & 1.518 & 0.079 & 28.90 \\
\hline \multicolumn{9}{|l|}{ Dry recycling } \\
\hline Paper and card & 38.8 & 46.7 & 3.4 & 0.125 & 9303.6 & 0.342 & 0.012 & 4.49 \\
\hline Glass & 19.6 & 23.6 & 1.7 & 0.063 & 4699.8 & 0.173 & 0.002 & 0.69 \\
\hline Metals (vi) & 16.8 & 20.2 & 1.5 & 0.054 & 4028.4 & 0.148 & 0.140 & 51.22 \\
\hline Plastics & 7.9 & 9.5 & 0.7 & 0.025 & 1894.3 & 0.070 & 0.001 & 0.38 \\
\hline Sub-Total & 83.1 & 100.0 & 7.3 & 0.267 & 19926.0 & 0.733 & 0.156 & 56.79 \\
\hline \multicolumn{9}{|l|}{ Organic waste } \\
\hline Food waste & 100.0 & 100.0 & 5.1 & 0.186 & 13849.3 & 0.509 & 0.000 & 0.00 \\
\hline Sub-Total & 100.0 & 100.0 & 5.1 & 0.186 & 13849.3 & 0.509 & 0.000 & 0.00 \\
\hline Total & & & 27.4 & 1.007 & 75068.5 & 2.760 & 0.235 & 85.69 \\
\hline
\end{tabular}


Note:

(i) Total waste includes waste from England, Wales, Scotland and Northern Ireland. Data obtained from DEFRA, valid in year 2016 [7].

4 (ii) Data obtained from Office for National Statistics, valid in year 2017 [51].

(iii) The value has been calculated by dividing the total amount of waste by number of households in the UK.

(iv) See Supplementary Materials: Table A.2 for the estimation of the amount of UK household waste streams based on England data. England generates 22.8 million tonnes of household waste per year, contributing to a total of 27.4 million tonnes per year of household waste in the UK. It has been assumed that each country in the UK generates the same fractions of waste stream as in England. Separately collected food waste has also been included in the total organic waste. (v) The composition of residual waste has been obtained from the VALORGAS report [38] and dry recycling from DEFRA's Digest of waste and resource statistics 2018 [7]. There is no information on the composition of organic waste stream.

(vi) All types of metals including WEEE, scrap metals and incineration bottom ash metals have been grouped under "Metals" in dry recycling stream.

A range of scenarios with variation in energy consumption and waste generation from households has been proposed, by altering energy supply, recycling rate and resource consumption, and inclusion of resource recovery from waste strategy, detailed below.

Base case scenario (Figure 7(a)): This scenario represents the current situation in the UK households where energy and waste domains have not been considered using a systems perspective. The electricity demand in household is supplied through grid electricity. Waste is generated from household at $45 \%$ recycling rate which consists of $26.5 \%$ of dry recycling and $18.5 \%$ of separately collected food waste. The remaining $55 \%$ of residual waste is sent to landfill $(29.1 \%)$ and incineration (70.9\%). It has been assumed that the incineration in the present context does not include energy 
1 Scenario 1 (Figure 7(b)): This scenario illustrates the conventional "waste-and-energy" model where

2 energy and waste domains in households have not been considered using a systems perspective. The 3 improvement has been made on the respective domains independently from each other either by

4 switching the electricity supply to residential-scale solar PV electricity while the household recycling 5 rate remains at $45 \%$ (Scenario 1(a)); or increasing household recycling rate from 45 to $60 \%$ while 6 using grid electricity (Scenario 1(b)); or a combination of both (Scenario 1(c)). This scenario does 7 not take into account the concept of resource recovery from waste into energy from the household 8 perspectives.

10 Scenario 2 (Figure 7(c)): This scenario presents a "waste-to-energy" model where energy and waste 11 domains have been considered as a system from household perspective. The household electricity 12 demand can be supplied from either grid electricity (Scenarios 2(a) and 2(b)) or residential-scale solar 13 PV electricity (Scenarios 2(c) and 2(d)), combined with electricity generated from EfW facilities. The 14 impact of increasing household recycling rate from 45 to $60 \%$ has also been investigated. This 15 scenario takes into account the resource recovery from waste into energy, i.e. all residual waste has 16 been sent to EfW facilities.

18 Scenario 3 (Figure 7(d)): This scenario presents a "reduced consumption" model. The energy and 19 waste domains have not been considered using a systems perspective and resource recovery from 20 waste into energy have not been accounted. The basis for source of electricity supply and household 21 recycling rate for this scenario is similar to the base case scenario (grid electricity and $45 \%$ household 22 recycling rate), except that the electricity demand has been reduced by $10 \%$ from $3100 \mathrm{kWh} / \mathrm{y}$ to $232790 \mathrm{kWh} / \mathrm{y}$ (Scenario 3(a)); and the amount of waste generation has been reduced by 10\% from 1007 $24 \mathrm{~kg} / \mathrm{y}$ to $906.3 \mathrm{~kg} / \mathrm{y}$ (Scenario 3(b)), in respective context. 


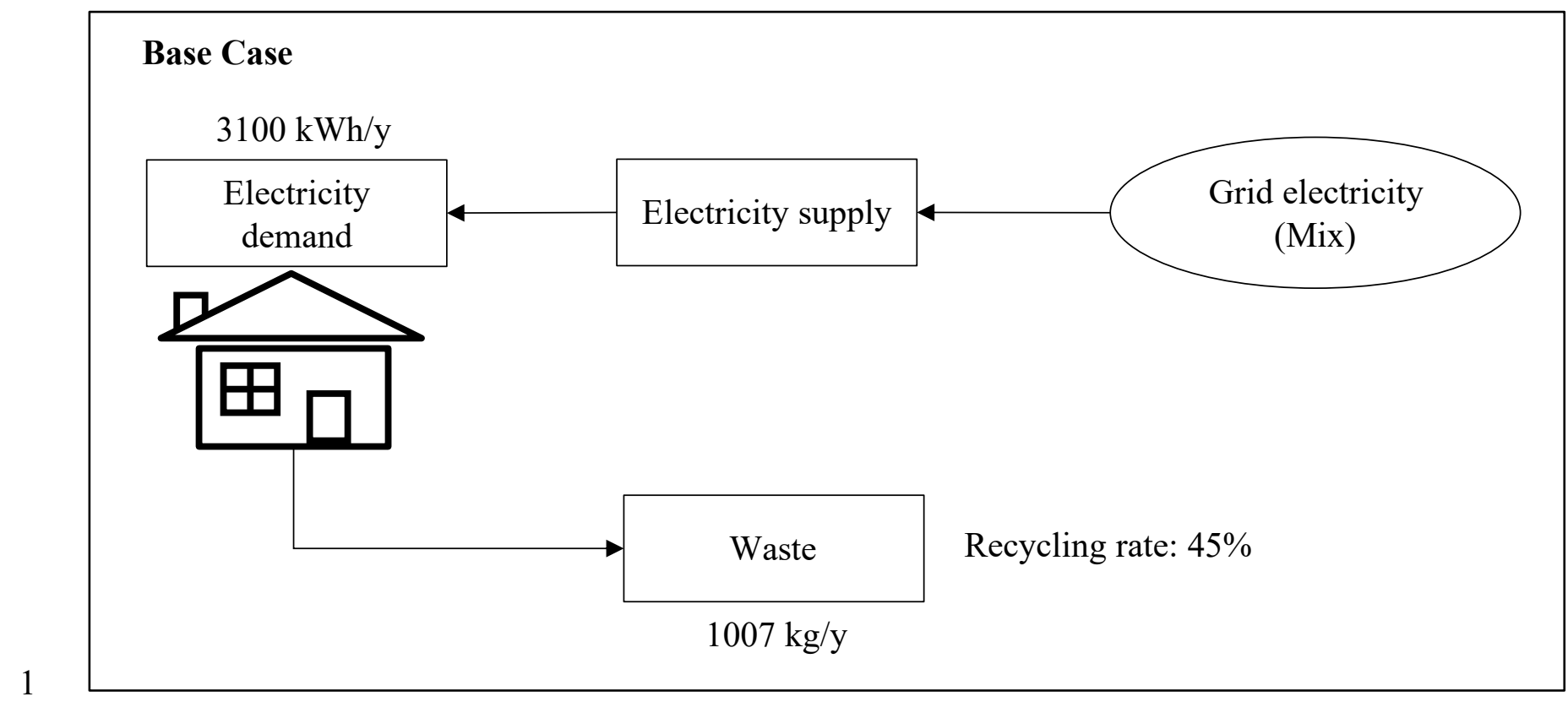

(a)

Scenario 1: "Waste-and-energy" model

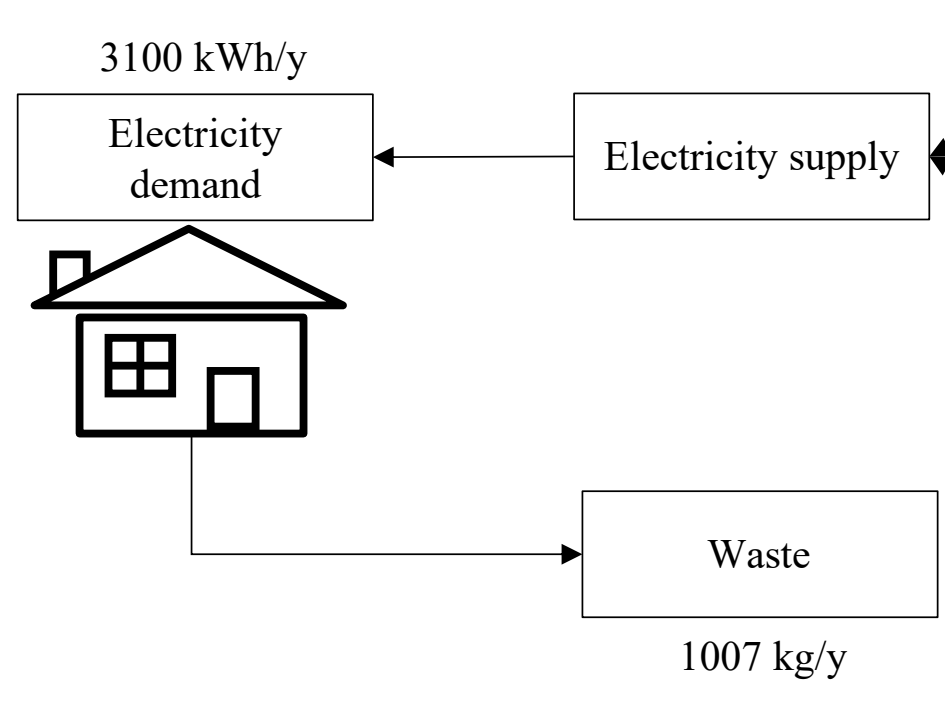

Recycling rate: $45 \% \rightarrow 60 \%$

3

4

(b)

5

6 


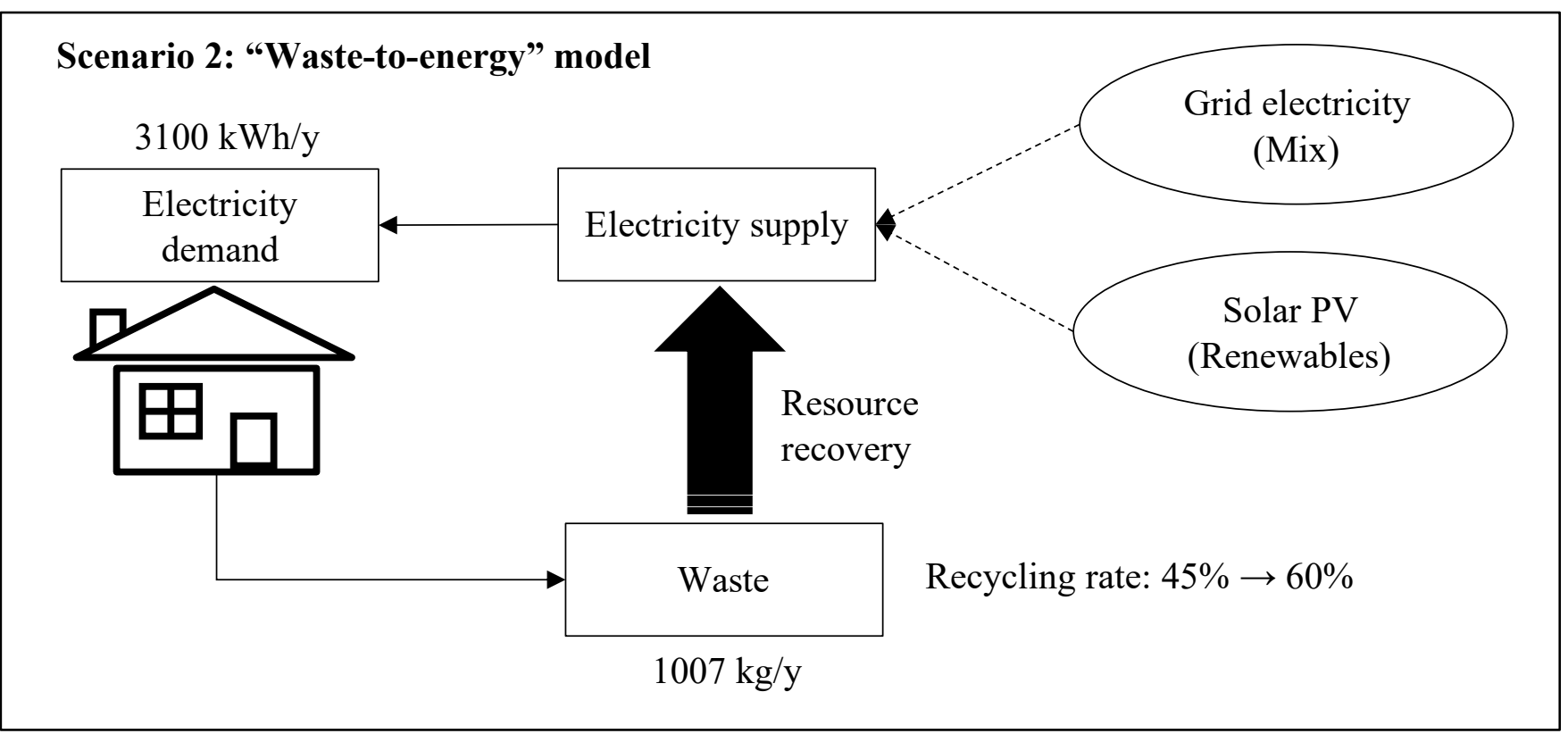

(c)

Scenario 3: "Reduced consumption" model

$3100 \mathrm{kWh} / \mathrm{y} \rightarrow 2790 \mathrm{kWh}(\downarrow 10 \%)$

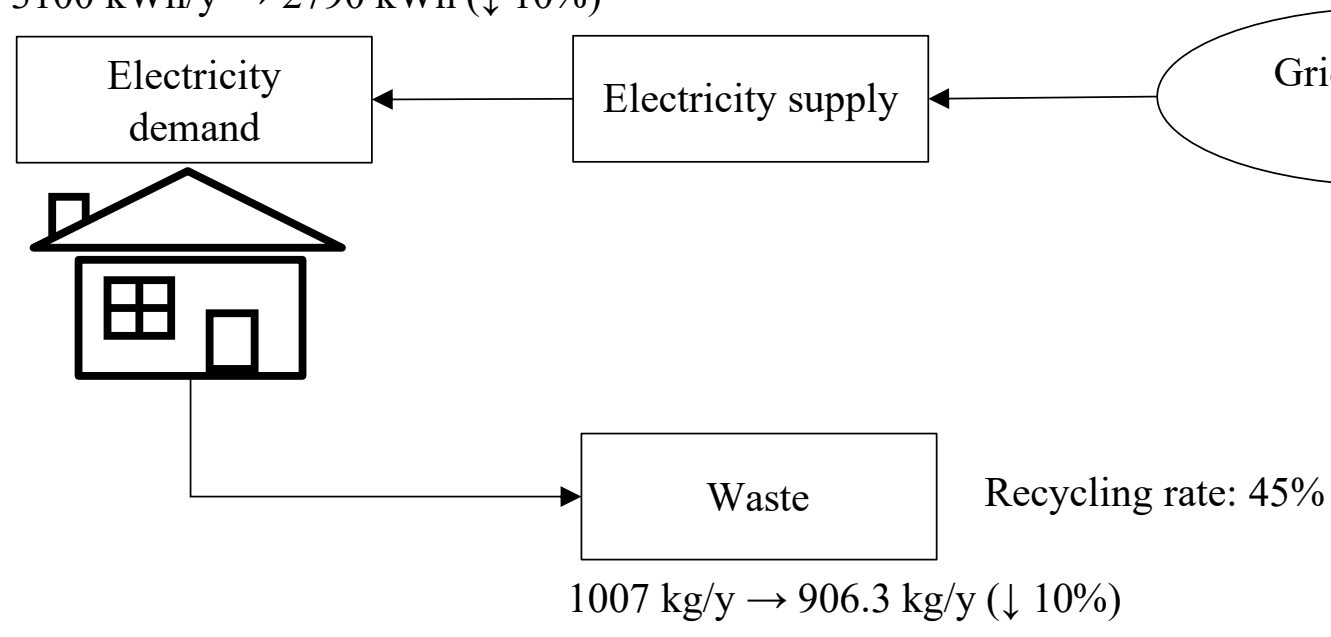

Figure 7: Scenario analysis for enhancing household resource efficiency. (a) Base case (b) Scenario 1 - "waste-andenergy"; (c) Scenario 2 - "waste-to-energy"; (d) Scenario 3 - "reduced consumption" model. 


\section{Sustainability Assessment}

3 The "waste-and-energy" model (Scenario 1), "waste-to-energy" model (Scenario 2) and "reduced consumption" model (Scenario 3), described in section 3.4, have been examined with respect to the economic (section 4.1), environmental (section 4.2) and social (section 4.3) dimensions.

\subsection{Economic cost-benefit analysis}

Table 6 presents the economic cost-benefit analysis for each scenario, taking into account the cost and saving on household electricity bill, income generated from incentives, council tax bill for waste management and indicative value of waste. The base case scenario shows $£ 558$ is incurred for a household with electricity consumption of $3100 \mathrm{kWh} / \mathrm{y}$; while the cost of council tax bill for waste management and indicative value of waste have been estimated at $£ 87.7$ and $£ 85.7$ per year, respectively, associated with $1007 \mathrm{~kg} / \mathrm{y}$ of waste generation per household at $45 \%$ recycling rate.

Scenario 1(a) demonstrates a potential cost saving of $£ 703$ per year with a payback period of 10.6 years if solar PV is adopted in household. This is attributed to the avoided cost of grid electricity of $£ 558$ (i.e. free electricity generated from solar PV) and an additional income of $£ 145$ per year generated from FiT (i.e. generation tariff gives $£ 128.9$ per year for $3400 \mathrm{kWh} / \mathrm{y}$ of electricity generation and $£ 16.1$ per year for $300 \mathrm{kWh} / \mathrm{y}$ of surplus electricity to be exported to the grid). Detailed calculation on solar PV related cost and income can be found in section 3.2. As there are no changes on the waste domain in this scenario, the council tax bill and indicative value of waste are identical to the base case. On the other hand, the energy domain in Scenario 1(b) is identical to the base case where grid electricity has been used, and therefore there are no savings from the energy domain. However, the increase of household recycling rate from 45 to $60 \%$ results in a net gain of $£ 6.2$ per year due to more materials recycled. Detailed calculations of council tax bill and indicative value of waste have been discussed in section 3.3. Combining the two approaches, i.e. switching to renewable solar PV for electricity generation and increasing household recycling rate, as demonstrated in Scenario 1(c) gives the highest savings/gain in both energy and waste domains.

Scenarios 2(a) and (b) examine the cost impacts if energy and waste domains are considered as a system, where part of the household electricity demand is substituted by electricity from waste while the remaining is still relying on grid electricity. If the price of electricity generated from waste is assumed to be the same as the standard price of grid electricity, i.e. $18 \mathrm{p} / \mathrm{kWh}$, then there are no obvious benefits as compared to the base case scenario and Scenario 1 . On the other hand, $£ 513.2$ per 
1 year of electricity bill reduction and additional $£ 158.4$ income generated from FiT can be obtained in 2 Scenario 2(c), if the electricity supply is switched to solar PV. Increasing recycling rate to $60 \%$ as 3 demonstrated in Scenario 2(d) results in less waste being sent to the EfW for energy recovery and 4 thus increasing the consumption of free electricity from solar PV. This in turn gives higher benefits

5 in terms of cost savings/income in the energy domain while at the same time gives higher net gain in 6 the waste domain.

7 Scenario 3 presents an alternative case of reducing energy consumption and waste generation, if no 8 changes are to be made on electricity supply and recycling rate. Intuitively, reducing $10 \%$ of 9 electricity consumption reduces the electricity bill (excluding standing charges) by 10\% compared to 10 the base case, as indicated in Scenario 3(a). However, reducing waste generation does not lead to any 11 reduction in the cost of council tax bills. This is because the current council tax scheme is based on a 12 fixed rate for every household within the same band (categorised based on property value) and it is 13 not a function of the amount of waste generation or recycling rate. A stricter penalty scheme such as 14 the pay-as-you-throw (PAYT) scheme or a more supportive incentivised scheme such as recycling 15 reward and deposit return schemes can be introduced to promote sustainable utilisation of resources, 16 lower waste generation and higher recycling rate at household. 
Table 6: Economic cost-benefit analysis.

\begin{tabular}{|c|c|c|c|c|c|c|c|c|c|c|c|}
\hline \multirow[b]{2}{*}{ Case } & & \multirow[t]{2}{*}{ Base Case } & \multicolumn{3}{|c|}{ Scenario 1} & \multicolumn{4}{|c|}{ Scenario 2} & \multirow{2}{*}{\multicolumn{2}{|c|}{$\begin{array}{c}\text { Scenario } 3 \\
\text { "Reduced } \\
\text { consumption" } \\
\text { model }\end{array}$}} \\
\hline & & & \multicolumn{3}{|c|}{ "Energy-and-waste" model } & \multicolumn{4}{|c|}{ "Waste-to-energy" model } & & \\
\hline \multicolumn{12}{|l|}{ Basis } \\
\hline Specification & $\underline{\text { Unit }}$ & & & & & & & & & & \\
\hline Total electricity consumption per household & $\mathrm{kWh} / \mathrm{y}$ & 3100 & 3100 & 3100 & 3100 & 3100 & 3100 & 3100 & 3100 & 2790 & 3100 \\
\hline Total waste generation per household & $\mathrm{kg} / \mathrm{y}$ & 1007 & 1007 & 1007 & 1007 & 1007 & 1007 & 1007 & 1007 & 1007 & 906.3 \\
\hline Source of electricity supply & & Grid & Solar PV & Grid & Solar PV & $\begin{array}{c}\text { Grid }+ \\
\text { Energy } \\
\text { from } \\
\text { waste } \\
\end{array}$ & $\begin{array}{c}\text { Grid + } \\
\text { Energy } \\
\text { from waste }\end{array}$ & $\begin{array}{l}\text { Solar PV + } \\
\text { Energy } \\
\text { from waste }\end{array}$ & $\begin{array}{l}\text { Solar PV + } \\
\text { Energy } \\
\text { from waste }\end{array}$ & Grid & Grid \\
\hline Household recycling rate & $\%$ & 45 & 45 & 60 & 60 & 45 & 60 & 45 & 60 & 45 & 45 \\
\hline Contribution of energy from waste & $\mathrm{kWh} / \mathrm{y}$ & 0 & 0 & 0 & 0 & 248.7 & 180.9 & 248.7 & 180.9 & 0 & 0 \\
\hline \multicolumn{12}{|l|}{ Energy domain (per household basis) } \\
\hline Cost of household electricity bill - grid electricity & $\mathfrak{f} / \mathbf{y}$ & 558.0 & 0.0 & 558.0 & 0.0 & 558.0 & 558.0 & 44.8 & 32.6 & 502.2 & 558.0 \\
\hline \multicolumn{12}{|l|}{ - by adopting solar $P V$} \\
\hline Saving on electricity bill (avoided cost) & $£ / y$ & 0.0 & 558.0 & 0.0 & 558.0 & 0.0 & 0.0 & 513.2 & 525.4 & 0.0 & 0.0 \\
\hline Income generated from FiT, generation (income) & $£ / y$ & 0.0 & 128.9 & 0.0 & 128.9 & 0.0 & 0.0 & 128.9 & 128.9 & 0.0 & 0.0 \\
\hline Income generated from FiT, export (income) & $£ / y$ & 0.0 & 16.1 & 0.0 & 16.1 & 0.0 & 0.0 & 29.5 & 25.9 & 0.0 & 0.0 \\
\hline Total saving/income for 1 year, with FiT & $\mathfrak{f} / \mathbf{y}$ & $\mathbf{0 . 0}$ & 703.0 & $\mathbf{0 . 0}$ & 703.0 & $\mathbf{0 . 0}$ & $\mathbf{0 . 0}$ & 671.6 & 680.2 & $\mathbf{0 . 0}$ & $\mathbf{0 . 0}$ \\
\hline Cost of PV & $£$ & 0.0 & 7468.0 & 0.0 & 7468.0 & 0.0 & 0.0 & 7468.0 & 7468.0 & 0.0 & 0.0 \\
\hline Payback period, with FiT & years & - & 10.6 & - & 10.6 & - & - & 11.1 & 11.0 & - & - \\
\hline Payback period, without FiT & years & - & 13.4 & - & 13.4 & - & - & 14.6 & 14.2 & - & - \\
\hline \multicolumn{12}{|l|}{ Waste domain (per household basis) } \\
\hline $\begin{array}{l}\text { Cost of council tax bill for waste collection and } \\
\text { treatment (fixed scheme) }\end{array}$ & $£ / y$ & 87.7 & 87.7 & 87.7 & 87.7 & 87.7 & 87.7 & 87.7 & 87.7 & 87.7 & 87.7 \\
\hline
\end{tabular}


2 LCIA has been performed for each scenario and the results are compared in Table 7 and Figure 8.

3 Scenario 1(a) shows significant improvement compared to the base case where negative impacts have 4 been obtained in all categories (except ODP), implying that employing solar PV gives the largest 5 potential in various impact savings. Increasing the household recycling rate from $45 \%$ to $60 \%$ in 6 Scenario 1(b) shows a smaller degree of improvement compared to Scenario 1(a). As expected, 7 Scenario 1(c) which combines the two approaches gives the highest impact savings in all categories. Hence, the analysis from Scenario 1 suggests that switching into renewable source of energy supply such as PV as well as increasing waste recycling are beneficial in view of minimising the environmental impacts, though the adoption of renewable energy source has the potential of achieving greater reduction compared to increasing waste recycling. The extent of impact savings achieved by substituting $1 \mathrm{kWh}$ of grid electricity as well as diverting $1 \mathrm{~kg}$ of residual waste from incineration and landfill is presented in Table 8 .

Scenario 2 offers a resource recovery perspective where contribution of energy generated from waste has been accounted and thereby reducing the reliance on conventional grid electricity or solar PV electricity. Scenario 2(a) presents a case where all the residual waste is sent to EfW facilities (i.e. complete diversion of waste from landfill). This enables $248.7 \mathrm{kWh} / \mathrm{y}$ of electricity to be generated which can then substitute part of the conventional grid electricity supplied to a household. The LCIA results for Scenario 2(a) shows ADP and GWP impact savings of 29\% and 25\%, respectively, compared to the base case scenario. Scenario 2(b) presents a case where less residual waste is sent to EfW attributed to an increase in recycling rate to $60 \%$ compared to Scenario 2(a) at $45 \%$, implying a substitution of $180.9 \mathrm{kWh}$ per year of electricity generated from waste supplied to household. This scenario shows lower impact across all categories (except ODP) compared with Scenario 2(a), suggesting that higher recycling rate brings greater benefits than sending more waste for energy recovery. It is also interesting to examine the impact saving that is contributed by switching the electricity supply to solar PV alongside electricity generated from waste. Scenario 2(c) can be compared against 2(a) while Scenario 2(d) can be compared against 2(b). The comparison shows that significant impact savings across all categories can be achieved. Scenario 2(d) demonstrates the most promising case among all scenarios under investigation as can be seen by the largest negative impact for all categories (except ODP). Although increasing recycling rate generally increases the impact

31 savings for ODP, however the substitution of conventional grid electricity which has a greater impact savings in ODP has been reduced in Scenarios 2(b) and 2(d). 
1 Whilst Scenarios 1 and 2 investigate the energy and waste management using the baseline values of

2 total energy consumption (i.e. $3100 \mathrm{kWh} / \mathrm{y}$ ) and waste generation (1007 kg/y) per household, Scenario

33 presents a case where the (a) consumption of electricity per household is reduced by $10 \%$ to 2790

$4 \mathrm{kWh} / \mathrm{y}$ and (b) waste generation per household is reduced by $10 \%$ to $906.3 \mathrm{~kg} / \mathrm{y}$. Scenario 3(a) indicates

5 that ADP and GWP impact savings of $24 \%$ and $21 \%$ can be achieved, compared to the base case

6 scenario, through reducing electricity consumption. On the other hand, Scenario 3(b) shows the highest

7 impact across all categories among all the scenarios under investigation. This is because the impact

8 savings for household waste management are mainly driven by the credits generated from re-

9 processing of dry recycling. Although reducing the amount of waste generation inevitably reduces the

10 credits generated from dry recycling in terms of impact savings, this should not be misinterpreted as

11 having lower waste generation has a negative impact on the environment. 
Table 7: Environmental LCIA for each scenario.

\begin{tabular}{|c|c|c|c|c|c|c|c|c|c|c|c|}
\hline \multirow{3}{*}{ Case } & & \multirow[t]{3}{*}{ Base Case } & \multicolumn{3}{|c|}{ Scenario 1} & \multicolumn{4}{|c|}{ Scenario 2} & \multirow{2}{*}{\multicolumn{2}{|c|}{$\begin{array}{c}\text { Scenario } 3 \\
\text { "Reduced consumption" } \\
\text { model }\end{array}$}} \\
\hline & & & \multicolumn{3}{|c|}{ "Waste-and-energy" model } & \multicolumn{4}{|c|}{ "Waste-to-energy" model } & & \\
\hline & & & a & b & c & $\mathbf{a}$ & b & c & d & $\mathbf{a}$ & b \\
\hline \multicolumn{12}{|l|}{ Basis } \\
\hline Specification & $\underline{\text { Unit }}$ & & & & & & & & & & \\
\hline $\begin{array}{l}\text { Total electricity } \\
\text { consumption per } \\
\text { household }\end{array}$ & $\mathrm{kWh} / \mathrm{y}$ & 3100 & 3100 & 3100 & 3100 & 3100 & 3100 & 3100 & 3100 & 2790 & 3100 \\
\hline $\begin{array}{l}\text { Total waste generation } \\
\text { per household }\end{array}$ & $\mathrm{kg} / \mathrm{y}$ & 1007 & 1007 & 1007 & 1007 & 1007 & 1007 & 1007 & 1007 & 1007 & 906.3 \\
\hline $\begin{array}{l}\text { Source of electricity } \\
\text { supply }\end{array}$ & & Grid & Solar PV & Grid & Solar PV & $\begin{array}{l}\text { Grid }+ \\
\text { Energy from } \\
\text { waste }\end{array}$ & $\begin{array}{l}\text { Grid }+ \\
\text { Energy from } \\
\text { waste }\end{array}$ & $\begin{array}{l}\text { Solar PV }+ \\
\text { Energy from } \\
\text { waste }\end{array}$ & $\begin{array}{l}\text { Solar PV + } \\
\text { Energy } \\
\text { from waste }\end{array}$ & Grid & Grid \\
\hline Household recycling rate & $\%$ & 45 & 45 & 60 & 60 & 45 & 60 & 45 & 60 & 45 & 45 \\
\hline $\begin{array}{l}\text { Distance of waste } \\
\text { transport }\end{array}$ & $\mathrm{km}$ & 50 & 50 & 50 & 50 & 50 & 50 & 50 & 50 & 50 & 50 \\
\hline $\begin{array}{l}\text { Contribution of energy } \\
\text { from waste }\end{array}$ & $\mathrm{kWh} / \mathrm{y}$ & 0 & 0 & 0 & 0 & 248.7 & 180.9 & 248.7 & 180.9 & 0 & 0 \\
\hline \multicolumn{12}{|l|}{ Composition } \\
\hline Residual waste & $\%$ & 55.0 & 55.0 & 40.0 & 40.0 & 55.0 & 40.0 & 55.0 & 40.0 & 55.0 & 55.0 \\
\hline Dry recycling & $\%$ & 26.5 & 26.5 & 34.0 & 34.0 & 26.5 & 34.0 & 26.5 & 34.0 & 26.5 & 26.5 \\
\hline $\begin{array}{l}\text { Food waste (separately } \\
\text { collected) }\end{array}$ & $\%$ & 18.5 & 18.5 & 26.0 & 26.0 & 18.5 & 26.0 & 18.5 & 26.0 & 18.5 & 18.5 \\
\hline \multicolumn{12}{|l|}{$\begin{array}{l}\text { Residual waste disposal } \\
\text { destination }\end{array}$} \\
\hline Incineration / EfW & $\%$ & 70.9 & 70.9 & 70.9 & 70.9 & 100 & 100 & 100 & 100 & 70.9 & 70.9 \\
\hline Landfill & $\%$ & 29.1 & 29.1 & 29.1 & 29.1 & 0 & 0 & 0 & 0 & 29.1 & 29.1 \\
\hline \multicolumn{12}{|l|}{ LCIA } \\
\hline Impact category & $\underline{\text { Unit }}$ & & & & & & & & & & \\
\hline
\end{tabular}




\begin{tabular}{|c|c|c|c|c|c|c|c|c|c|c|c|}
\hline $\begin{array}{l}\text { Abiotic depletion } \\
\text { potential (ADP), element }\end{array}$ & kg Sb eq. & 0.0006 & 0.0090 & 0.0002 & 0.0086 & -0.0001 & -0.0003 & 0.0076 & 0.0076 & 0.0005 & 0.0008 \\
\hline $\begin{array}{l}\text { Abiotic depletion } \\
\text { potential (ADP), fossil } \\
\text { fuels }\end{array}$ & MJ & 17259.0 & -8954.2 & 13591.3 & -12621.9 & 12239.8 & 9960.7 & -11870.6 & -14723.2 & 14368.9 & 18423.2 \\
\hline $\begin{array}{l}\text { Global warming } \\
\text { potential (GWP), } 100 \\
\text { years }\end{array}$ & $\mathrm{kg} \mathrm{CO}_{2}$ eq. & 1632.5 & -694.6 & 1176.2 & -1150.9 & 1227.0 & 883.4 & -913.5 & -1308.0 & 1374.6 & 1727.2 \\
\hline $\begin{array}{l}\text { Ozone depletion } \\
\text { potential (ODP) }\end{array}$ & $\begin{array}{l}\text { kg CFC-11 } \\
\text { eq. }\end{array}$ & 0.00006 & 0.00000 & 0.0000 & 0.0000 & -0.00004 & -0.00002 & -0.00009 & -0.00008 & 0.00005 & 0.00006 \\
\hline $\begin{array}{l}\text { Human toxicity potential } \\
\text { (HTP) }\end{array}$ & $\begin{array}{l}\mathrm{kg} 1,4-\mathrm{DB} \\
\text { eq. }\end{array}$ & 2195.1 & 1841.7 & 1175.2 & 821.8 & 3078.2 & 1819.1 & 2753.1 & 1486.3 & 2125.9 & 2044.8 \\
\hline $\begin{array}{l}\text { Freshwater aquatic } \\
\text { ecotoxicity potential } \\
\text { (FAEP) }\end{array}$ & $\begin{array}{c}\text { kg } 1,4-\mathrm{DB} \\
\text { eq. }\end{array}$ & 17072.8 & 16433.7 & 12370.4 & 11731.3 & 23288.3 & 16891.8 & 22700.5 & 16290.0 & 16959.4 & 15478.9 \\
\hline $\begin{array}{l}\text { Marine aquatic } \\
\text { ecotoxicity potential } \\
\text { (MAEP) }\end{array}$ & $\begin{array}{c}\mathrm{kg} 1,4-\mathrm{DB} \\
\text { eq. }\end{array}$ & 86902502.7 & 84687218.6 & 58459915.4 & 56244631.3 & 124673862.8 & 85945382.9 & 122636286.4 & 83859340.8 & 86572695.2 & 78542060.0 \\
\hline $\begin{array}{l}\text { Terrestrial ecotoxicity } \\
\text { potential (TEP) }\end{array}$ & $\begin{array}{c}\text { kg 1,4-DB } \\
\text { eq. }\end{array}$ & 9.88 & -1.14 & 9.05 & -1.97 & 7.16 & 7.07 & $\mathrm{v} 2.98$ & -3.30 & 8.69 & 10.08 \\
\hline $\begin{array}{l}\text { Photochemical oxidant } \\
\text { creation potential } \\
(\mathrm{POCP})\end{array}$ & $\mathrm{kg} \mathrm{C}_{2} \mathrm{H}_{4}$ eq. & 0.118 & -0.311 & -0.0104 & -0.4395 & -0.010 & -0.103 & -0.405 & -0.507 & 0.067 & 0.158 \\
\hline $\begin{array}{l}\text { Acidification potential } \\
\text { (AP) }\end{array}$ & $\mathrm{kg} \mathrm{SO}_{2}$ eq. & 5.20 & -5.46 & 3.0592 & -7.6020 & 2.84 & 1.35 & -6.96 & -8.69 & 3.98 & 5.91 \\
\hline $\begin{array}{l}\text { Eutrophication potential } \\
\text { (EP) }\end{array}$ & $\mathrm{kg} \mathrm{PO}_{4}{ }^{3-}$ eq. & 2.05 & -0.22 & 1.4633 & -0.7998 & 1.26 & 0.89 & -0.82 & -1.24 & 1.74 & 2.15 \\
\hline
\end{tabular}

Note:

$\mathrm{Sb}$ : antimony; $\mathrm{CFC}$ : Chlorofluorocarbon; 1,4-DB: 1,4-dicholorobenzene; $\mathrm{C}_{2} \mathrm{H}_{4}$ : ethane; $\mathrm{SO}_{2}$ : sulphur dioxide; $\mathrm{PO}_{4}{ }^{3-}$ : phosphate.

More information can be found in Supplementary Materials: Appendix B.

Incineration in Scenarios 1 and 3 does not include energy recovery; while $100 \%$ residual waste is sent to EfW (i.e. energy-from-waste facility or incineration with energy recovery) has been assumed in Scenario 2 . 
Table 8: Impact saving analysis for substitution of $1 \mathrm{kWh}$ of grid electricity and recycling of $1 \mathrm{~kg}$ of waste.

\begin{tabular}{|c|c|c|c|}
\hline Impact category & Unit & $\begin{array}{l}\text { Impact saving from } \\
\text { substituting } 1 \mathrm{kWh} \text { of } \\
\text { grid electricity }\end{array}$ & $\begin{array}{l}\text { Impact saving from } \\
\text { diverting } 1 \mathrm{~kg} \text { of } \\
\text { residual waste from } \\
\text { incineration and } \\
\text { landfill }\end{array}$ \\
\hline Abiotic depletion potential (ADP), element & kg Sb eq. & -0.0000006 & 0.0000003 \\
\hline Abiotic depletion potential (ADP), fossil fuels & MJ & -9.32 & 0.339 \\
\hline Global warming potential (GWP), 100 years & $\mathrm{kg} \mathrm{CO} 2$ eq. & -0.83 & 0.554 \\
\hline Ozone depletion potential (ODP) & kg CFC-11 eq. & -0.00000003 & 0.0000000 \\
\hline Human toxicity potential (HTP) & kg 1,4-DB eq. & -0.22 & 4.68 \\
\hline Freshwater aquatic ecotoxicity potential (FAEP) & kg 1,4-DB eq. & -0.37 & 29.9 \\
\hline Marine aquatic ecotoxicity potential (MAEP) & kg 1,4-DB eq. & -1063.9 & 169228.9 \\
\hline Terrestrial ecotoxicity potential (TEP) & kg 1,4-DB eq. & -0.00383 & 0.0008658 \\
\hline Photochemical oxidant creation potential (POCP) & $\mathrm{kg} \mathrm{C}_{2} \mathrm{H}_{4}$ eq. & -0.00017 & 0.0000450 \\
\hline Acidification potential (AP) & $\mathrm{kg} \mathrm{SO} \mathrm{S}_{2}$ eq. & -0.00395 & 0.0002106 \\
\hline Eutrophication potential (EP) & $\mathrm{kg} \mathrm{PO}_{4}^{-}$eq. & -0.00099 & 0.0009630 \\
\hline
\end{tabular}




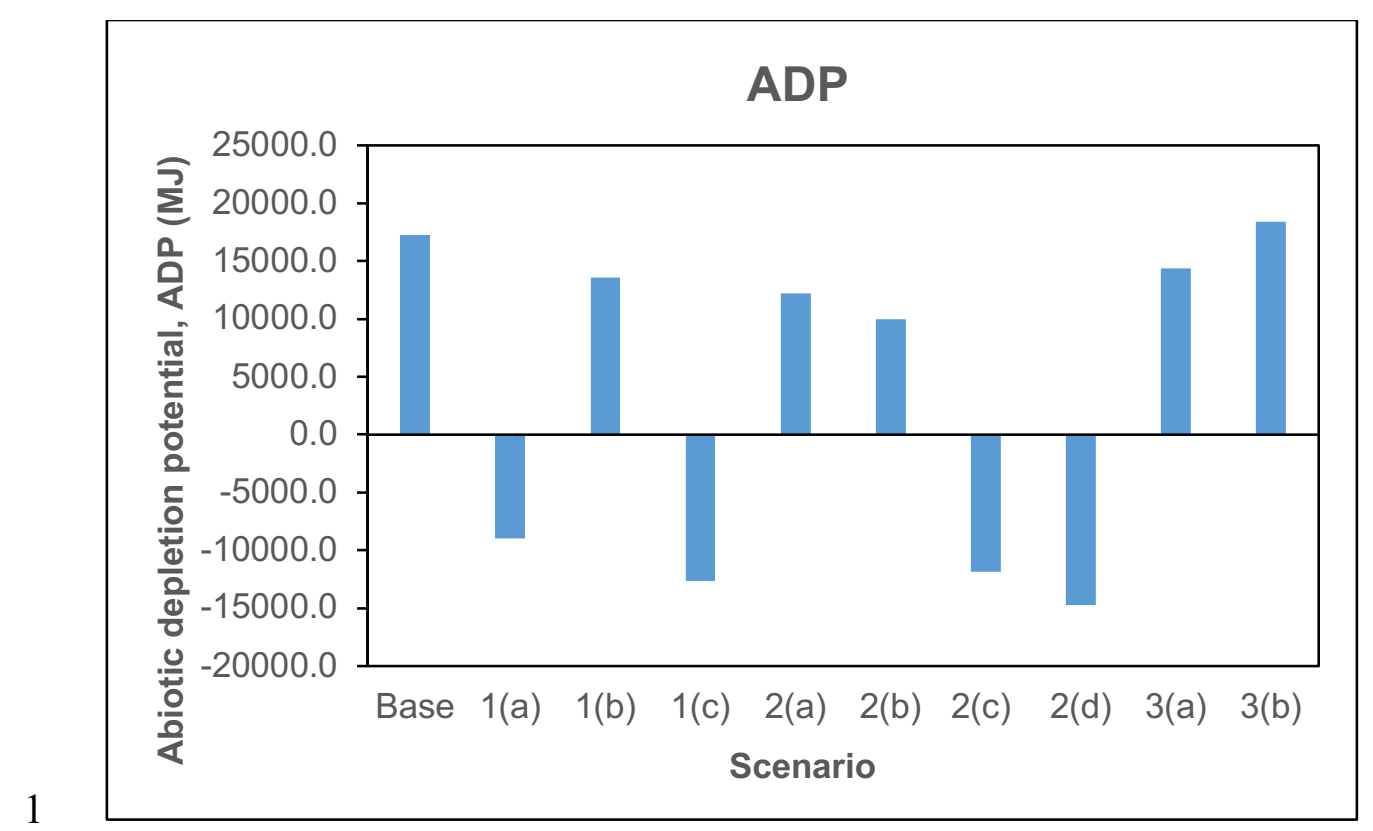

2

(a)

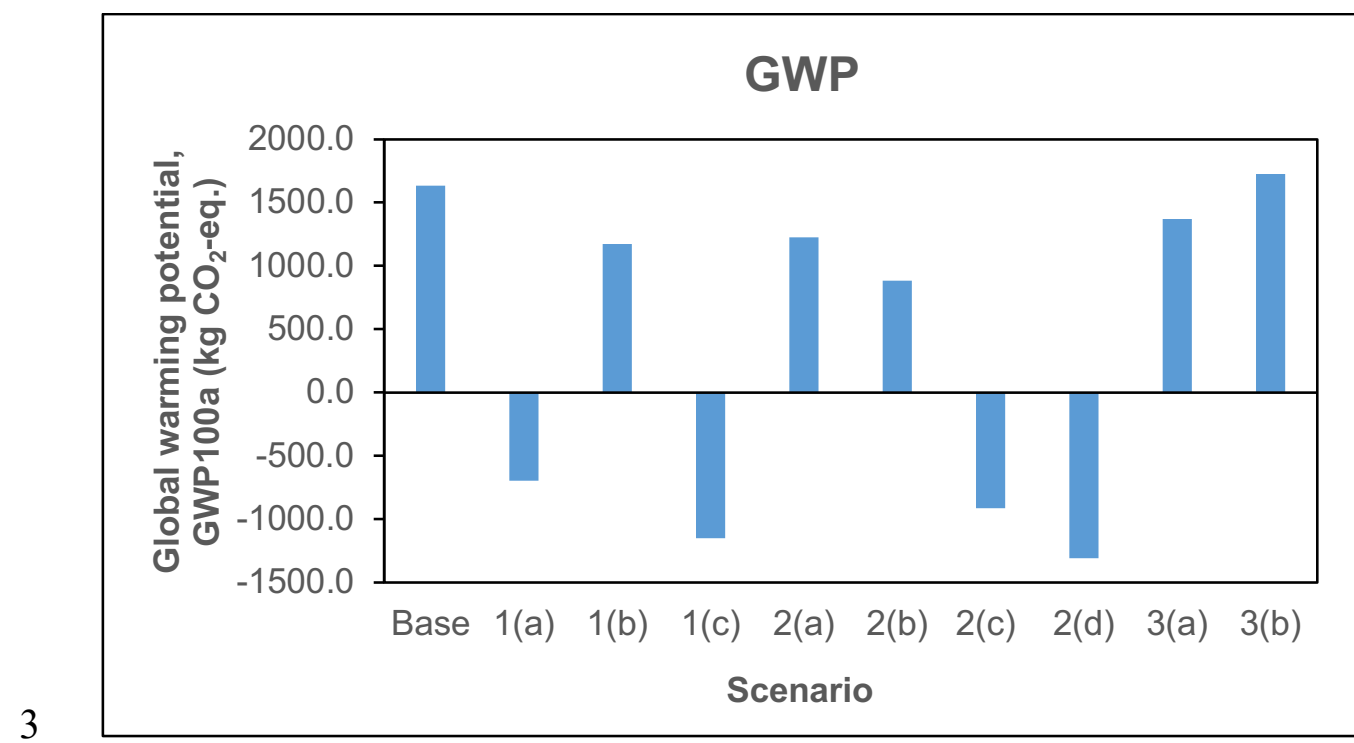

4

(b) 


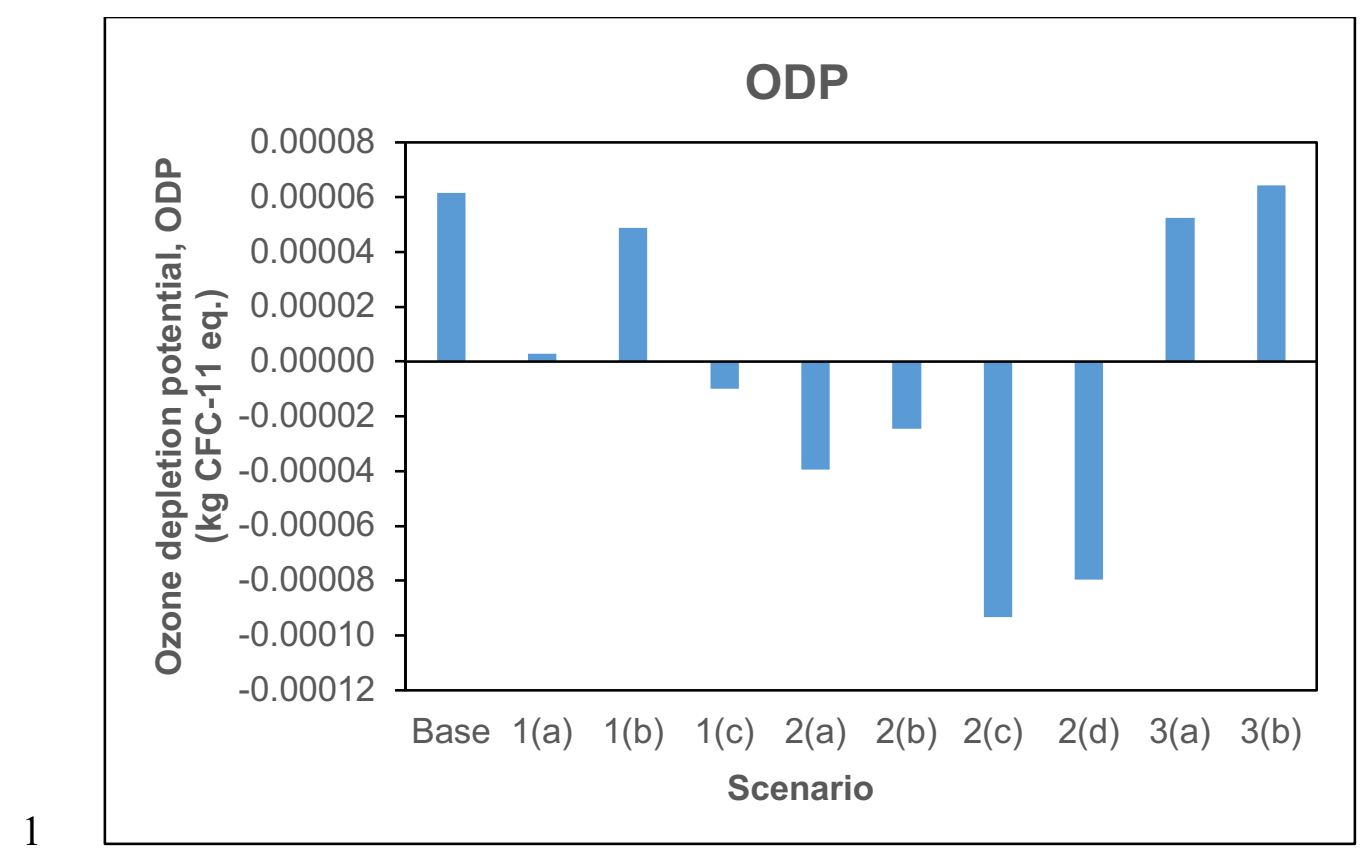

2

(c)

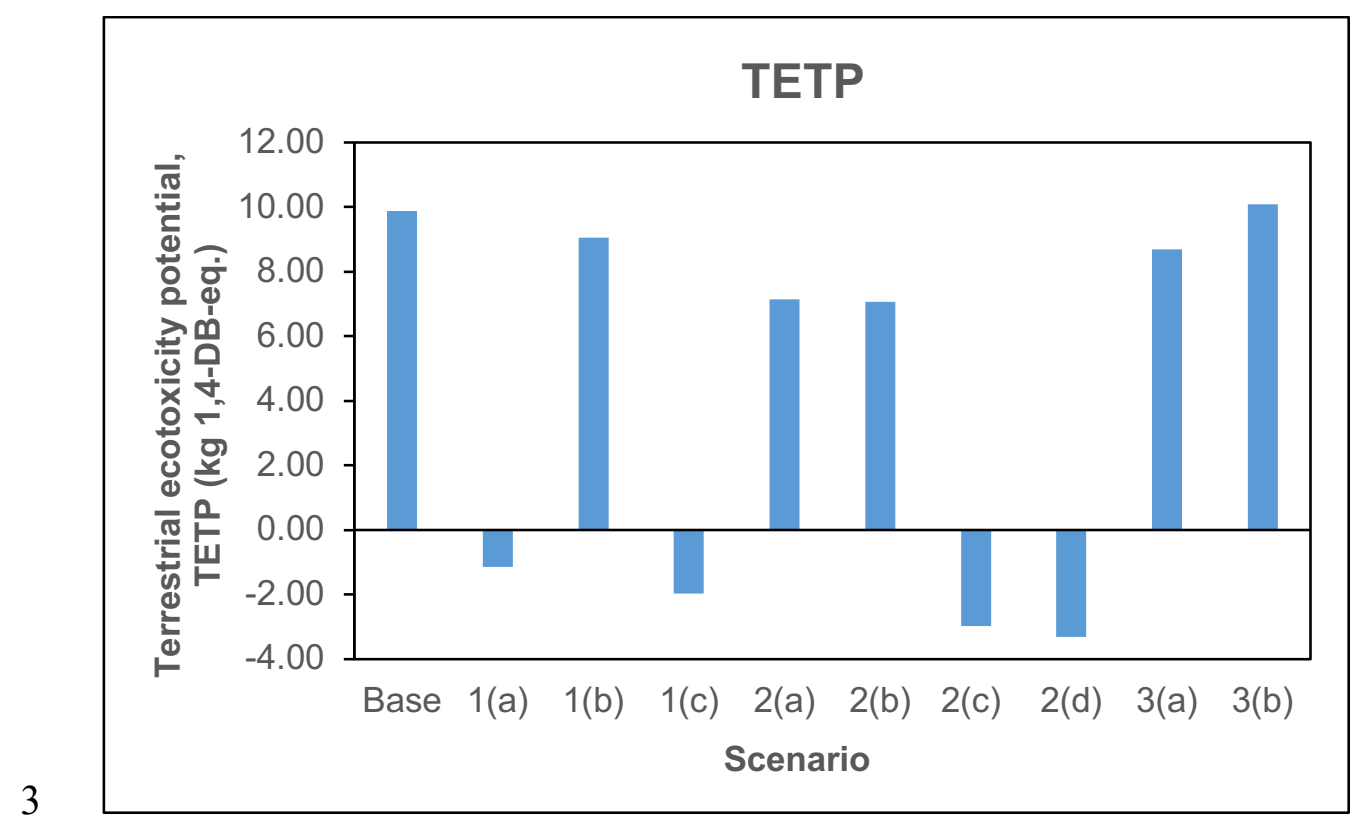

4

(d) 


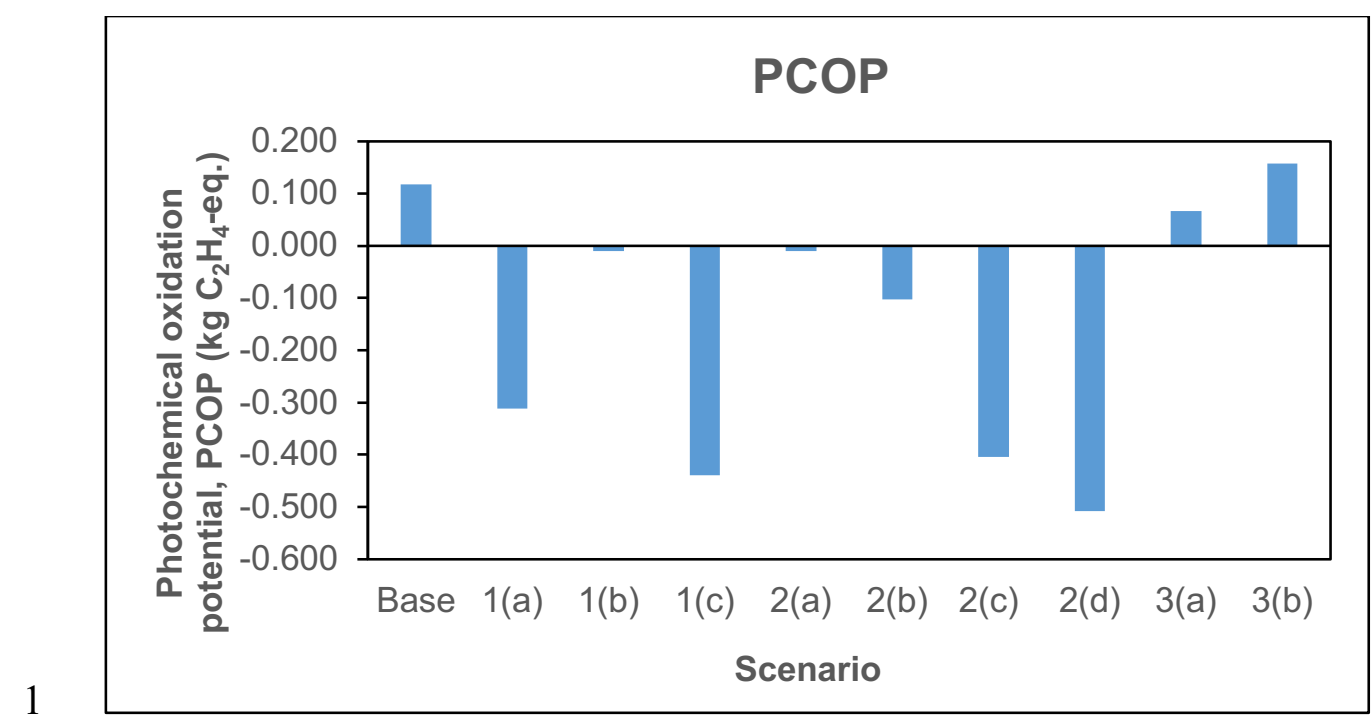

(e)

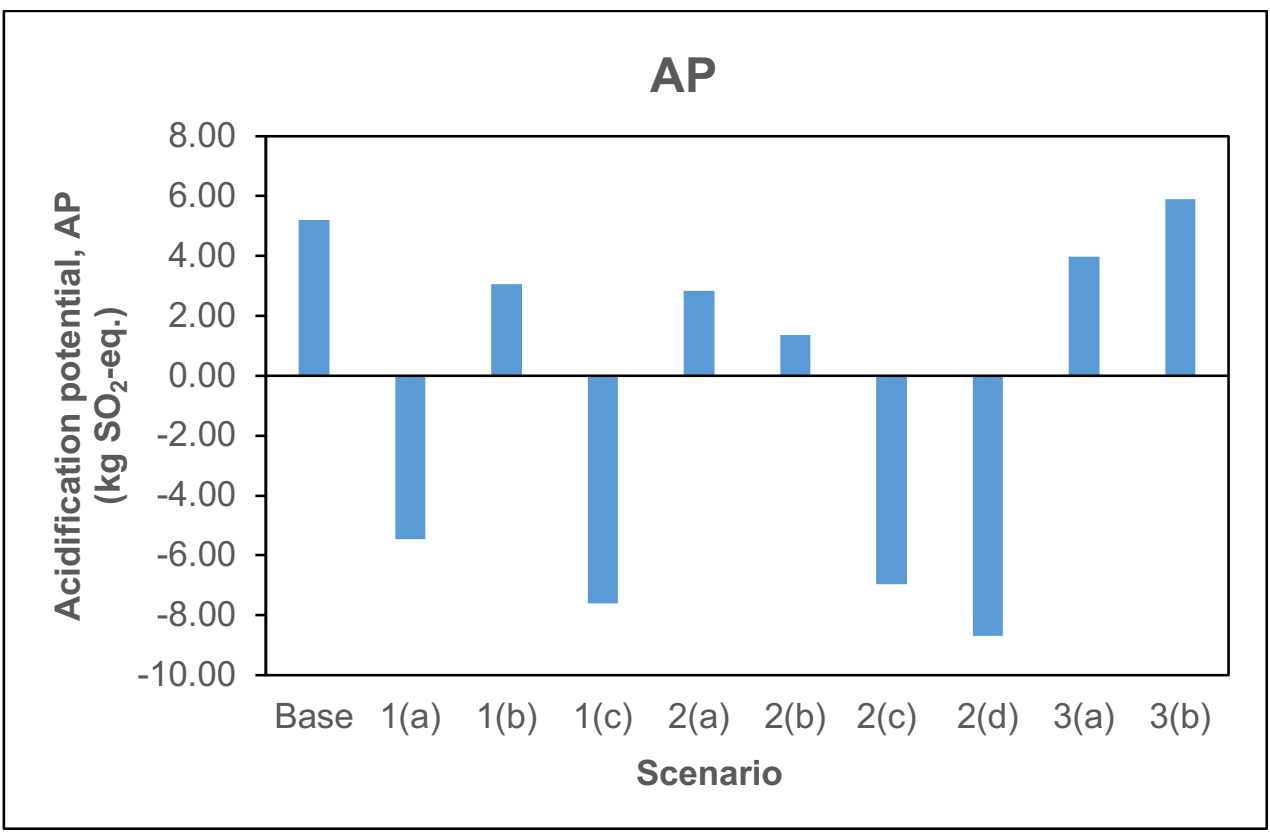

(f) 


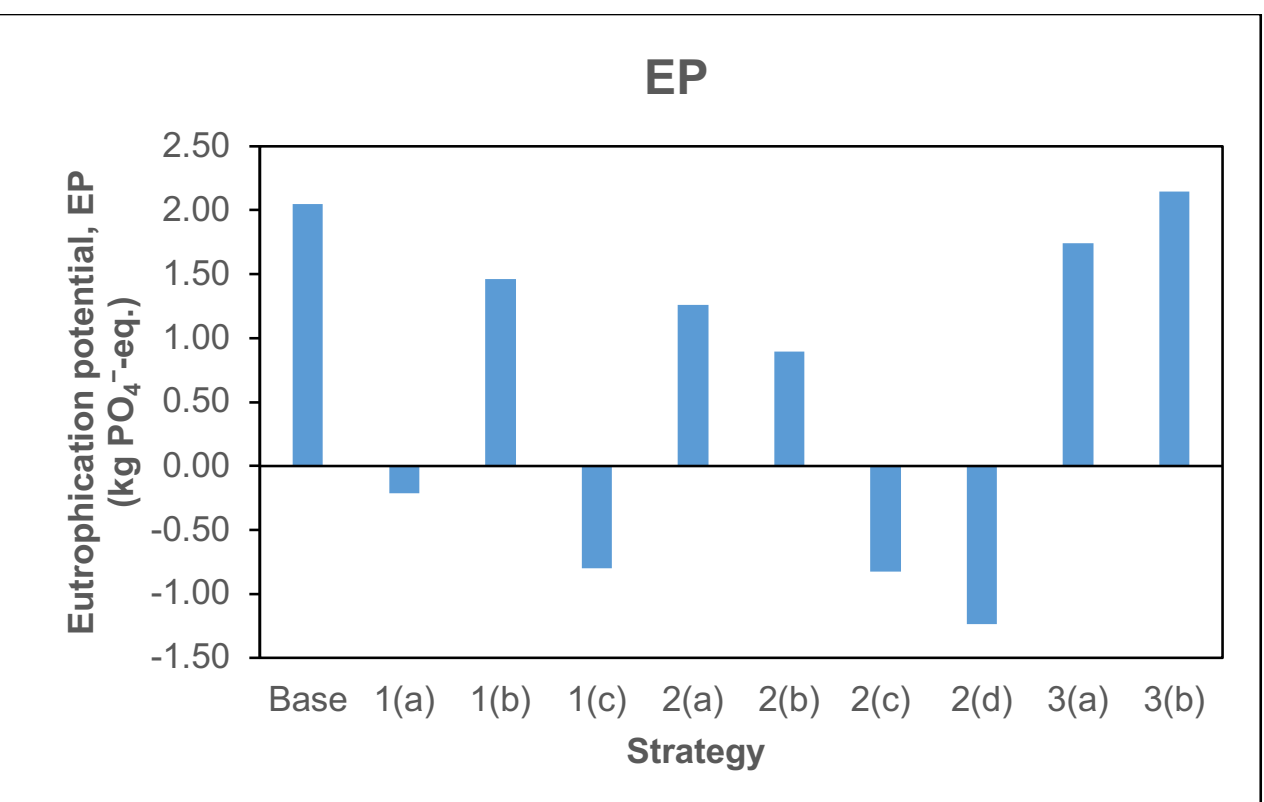

Figure 8: Comparison of LCIA for each scenario.

5 The damage impact to human health has been analysed for each scenario and is illustrated in Figure

69 . Negative damage impact (i.e. less harmful to human health) can be found in scenarios where solar $7 \quad$ PV has been adopted, i.e. Scenarios 1(a), 1(c), 2(c) and 2(d). Scenario 2(d) has achieved the lowest 8 damage impact to human health among all scenarios attributed to the avoided impacts due to diversion 9 from grid electricity and also credits generated from energy from waste and higher recycling rate. 10 Almost every scenario has shown improvement in terms of reduced damage impact compared to the 11 base case scenario apart from Scenario 3(b). The impact saving is lower because less waste materials 12 are recycle. It should not be misinterpreted that reducing waste generation from household does not 13 give any potential impact saving. Instead, it implies that reducing waste generation in household by $1410 \%$ alone is not sufficient to make a significant improvement to lowering the damage impact to 15 human health. 


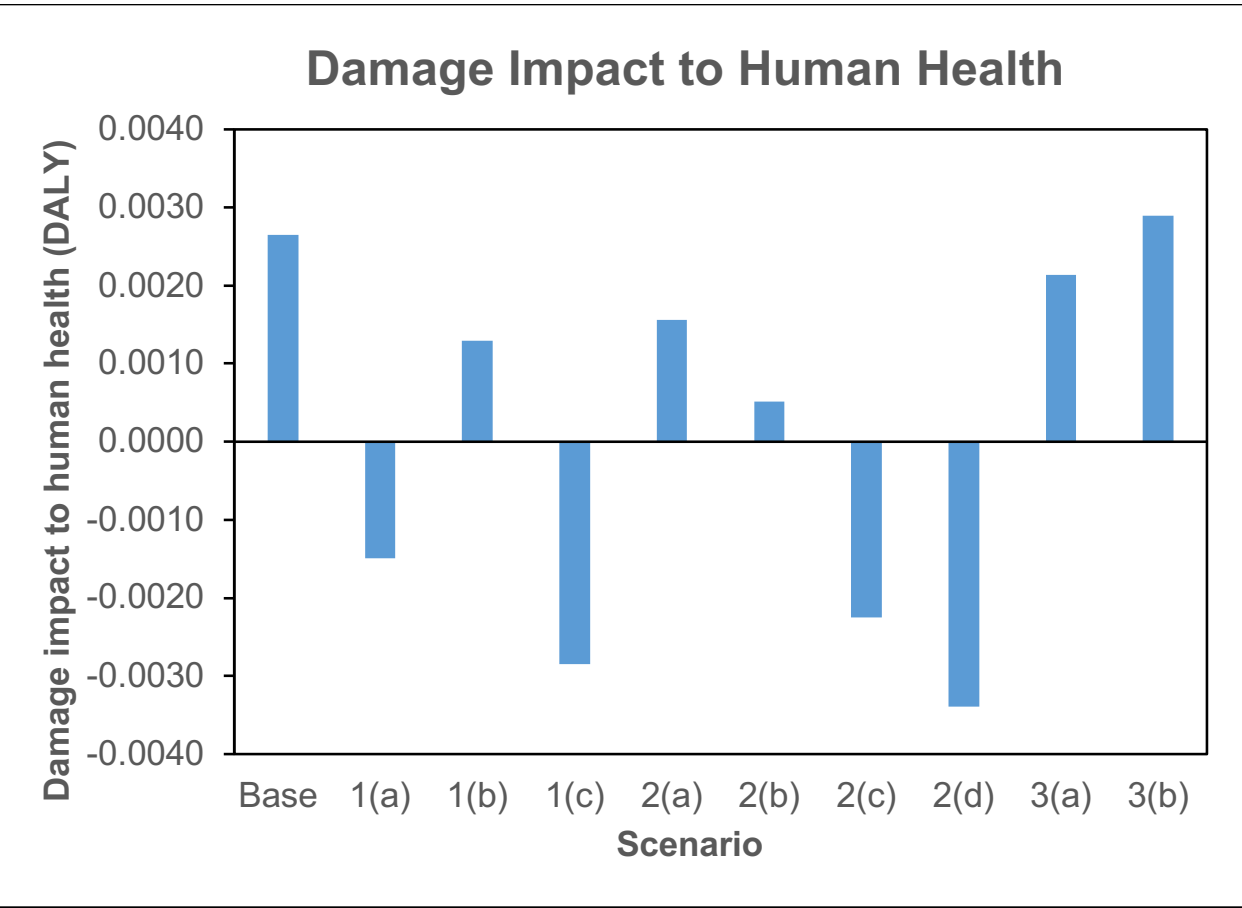

2 Figure 9: Damage impact to human health.

\subsection{Assessment of social dimension}

The social dimension has been assessed in terms of public acceptance and participation. The latest survey conducted by YouGov and ClientEarth indicated that more than $60 \%$ of the UK consumers are willing to install solar panel and energy storage device at home, provided that greater assistance from the government is given [52]. Up to September 2019, the number of solar panels installed in the UK households have reached 944,072 units (the capacity of solar PV system of less than $4 \mathrm{~kW}$ ), with 11 a significant rise from 5,057 units over the past 10 years since 2010 [53], which mainly attributed to 12 the introduction of FiT in 2010. Balcombe et al. [54] discussed the motivations and barriers for 13 adopting solar PV and other types of microgeneration systems in the UK, by considering finance, 14 environment, security of supply, uncertainty and trust, inconvenience and impact on residence. The uptake of solar PV technologies has benefited from government subsidies and lower installation cost, 16 however current policies do not addressed the major barrier in relation to the capital cost of PV [54]. Despite the gradual price drop in solar PV which may increase uptake of the technology, the study [54] also pointed out that it is uncertain whether consumers are willing to pay for the installation though they are convinced that solar PV can bring certain environmental benefits. Some households may be unable to install solar PV on their rooftop, for example, if their roof is unsuitable, they are in an apartment building or if they are renting. On the other hand, recycling rates are influenced by a number of factors such as deprivation level, household density, political leadership, and governance 
1 and contract [55]. More evidence is needed to further conclude the dominating factors, the impact on the public acceptance and whether a reward or penalty scheme is more appropriate in the UK context.

3 Overall, the paradigm shift is mainly driven by the monetary benefits through either cost reduction on energy and council tax bills or income generated from government incentives. Based on the analysis in sections 4.1 and 4.2, Scenarios 1(a), 1(c), 2(c) and 2(d) are most likely to be accepted by majority of the public because of the significant cost savings from electricity bills and income generated from FiT.

\subsection{Discussions}

10 The discussion in this section has combined the results of sustainability assessment from sections 4.1 11 to 4.3 and has presented in a digestible format which is useful for policy-making. The results for all impact categories have been presented for the sake of completeness. In the present context, it is more crucial to focus on ADP and GWP since these two impact categories are highly relevant to resource utilisation and emissions related to energy and waste which should be considered from the household perspective and in policy making. Hence, exhaustive discussions on other impact categories will not be included here.

\section{Energy domain in household}

For a household which demands $3100 \mathrm{kWh}$ of electricity supply annually (associated with an electricity bills of $£ 558$ per year and GWP of $2579.5 \mathrm{~kg} \mathrm{CO}_{2}$-equivalent/year):

- Switching from grid electricity to renewable solar PV requires an additional capital investment of $£ 7468$ for a $4 \mathrm{~kW}$ solar panel, however resulting in a total saving/income of $£ 703$ per year with an expectation of a minimum payback period of 10.6 years if the current FiT rate is considered. From the environmental standpoint, this transformation in energy supply leads to $90 \%$ reduction in GWP or $2327.2 \mathrm{~kg} \mathrm{CO}_{2}$-equivalent/year of GWP impact saving. [Comparing Base Case and Scenario 1(a)]

- Introducing energy from waste into the existing household electricity supply system while substituting part of the conventional grid electricity does not offer any cost reduction, if the price of the electricity generated from waste is assumed to be the same as the price of conventional grid electricity. The GWP saving is only $8 \%$, equivalent to $206.9 \mathrm{~kg} \mathrm{CO}_{2}$ equivalent/year. [Comparing Base Case and Scenario 2(a)]

- If the energy supply system in household using grid electricity remains unchanged and assuming that $10 \%$ of reduction in energy consumption can be attained, a similar percentage 


\section{Waste domain in household}

For a household which generates $1007 \mathrm{~kg}$ of waste annually at recycling rate of $45 \%$ (associated with

$£ 85.7$ per year of indicative value of waste and GWP of $-956.9 \mathrm{~kg} \mathrm{CO}_{2}$-equivalent/year):

of cost and GWP reduction are expected. Despite the 10\% reduction in energy consumption seen that the cost and environmental benefits are not particularly significant. [Comparing Base Case and Scenario 3(a)]

- From the social perspective, using renewable solar PV can attain 80\% reduction in damage impact of human health compared to using grid electricity. [Comparing Base Case with all scenarios adopting solar PV, i.e. Scenario 1(a), 1(c), 2(c) and 2(d)]

- Increasing the recycling rate to $60 \%$ increases the value of waste by $9 \%$, while achieving GWP savings of $46.6 \%$ to $-1403.2 \mathrm{~kg} \mathrm{CO}_{2}$-equivalent/year. [Comparing Base Case and Scenario 1(b)]

- Substituting $8 \%$ of electricity supply using the electricity generated from residual waste increases the GWP saving by $20 \%$ to $-1145.6 \mathrm{~kg} \mathrm{CO}_{2}$-equivalent/year. Further increasing the recycling rate to $60 \%$ leads to $-1545.6 \mathrm{~kg} \mathrm{CO}$-equivalent/year or $61 \% \mathrm{GWP}$ savings. [Comparing Base Case and Scenarios 2(a) and 2(b)]

- If the recycling rate in household remains unchanged and assuming that $10 \%$ of reduction in waste generation can be attained, a similar percentage of cost and GWP reduction are expected. Despite the $10 \%$ reduction in waste generation could be a realistic and socially-acceptable approach through behavioural change, it can be seen that the cost and environmental benefits are not particularly significant. [Comparing Base Case and Scenario 3(b)]

\section{$\underline{\text { Energy and waste domains }}$}

The "waste-and-energy" model presented in this study shows the typical household perspective in energy and waste management. The economic and environmental assessment indicate that switching to solar PV for energy supply is able to bring significant benefits in terms of cost and environmental savings as discussed above. Although increasing recycling rate from 45 to $60 \%$ alone may not have much impact on cost savings due to the fixed council tax rate, it is still able to reduce GWP by $28 \%$ (i.e. $1632.5 \mathrm{~kg} \mathrm{CO}_{2}$-equivalent/year in Base Case to $1176.2 \mathrm{~kg} \mathrm{CO}_{2}$-equivalent/year in Scenario 1(b)). Switching the energy supply system to solar PV in parallel with increasing recycling rate from 45 to $60 \%$ gives the best performed scenario within the "waste-and-energy" model, giving GWP of -1150.9 
$1 \mathrm{~kg} \mathrm{CO}$-equivalent/year and total saving/income of $£ 703$ per year, on one household basis. This is a

2 strategy which is achievable within short to medium term through technological transformation and

3 behavioural change.

4 The "waste-to-energy" model is not a common status quo systems perspective at household but it is 5 an emerging concept at national level. There has been question whether this is the right approach to 6 be undertaken in the future if recovery of waste is to be regarded as the lowest priority in the waste 7 hierarchy. The economic benefits are not as promising as the "energy-and-waste" model particularly 8 if solar PV is not adopted. Another reason is because the same electricity price has been assumed for 9 both grid electricity and electricity generated from waste. In spite of this, the combined approaches 10 through switching into solar PV, increasing recycling rate from 45 to $60 \%$ and $100 \%$ of residual waste 11 diverted into EfW for energy recovery offer significant environmental benefits, i.e. GWP of -1308 $12 \mathrm{~kg} \mathrm{CO}$-equivalent/year, which stands as the best performed scenario in terms of environmental 13 impact savings among all scenarios under consideration. This is also a practical strategy but it requires 14 a longer time for the technological transformation and behavioural change. Although it is desirable 15 to divert all residual waste into recycling stream, this has not been seen as a practical scenario.

16 "Reducing consumption" model is a special case in this study where it does not rely on any 17 technological transformation and assuming that the current practice and perspective remains unchanged. This scenario with grid electricity and no increase in recycling rate does not show distinctive change since $10 \%$ reduction in either energy consumption or waste generation has been considered

\section{Establishing ideal "what-if" cases for the UK}

In the UK with 27.2 million of households, a total GWP savings of 70 million tonne $\mathrm{CO}_{2}$ equivalent/year can be attained if all households are to adopt renewable solar PV, which avoids 84.3 TWh total grid electricity supply to all UK households. If all the materials in the residual waste stream of UK households can be diverted into dry recycling stream, this generates additional $£ 786$ million/y of revenue while avoiding GWP of 8.4 million $\mathrm{C}_{2}$-equivalent/year in total at the UK level. If all residual waste stream ( $55 \%$ of total waste from household) is diverted into energy recovery at the UK level, this creates $6.8 \mathrm{TWh}$ of additional electricity, corresponding to 5.6 million $\mathrm{t} \mathrm{CO}_{2}$ equivalent/year of GWP credit generation. 
2 Households are highly resource intensive in terms of energy consumption and waste generation. A 3 systems approach is thus needed to unlock the potential of resource recovery at household level which could address resource efficiency, fuel poverty and environmental issues more effectively at the national level. The present study complements existing research in the individual domains of household energy and waste by considering energy supply and demand, waste generation and resource recovery, trilaterally and treating them as a system. The Systems Thinking Approach to Resource Recovery (STARR) framework which consists of system analysis, scenario creation and sustainability assessment has been applied to identify potential improvements. Material flow analysis approach has unveiled the energy consumption in household with respect to appliances as well as waste generation by categories of food waste, papers and cards, glass, plastics and metals. The waste streams from household have been categorised into residual waste, dry recycling and organic waste stream and these streams have been further explored in terms of resource recovery potential. The economic value and costs of the energy and waste streams in household have been evaluated by establishing a base case to represent the implications associated with the current scenario. In this study, three models of energy and waste in households have been examined, including "waste-andenergy", "waste-to-energy" and "reduced consumption" models. These models have been further explored through different scenarios such as adoption of renewable solar PV energy supply, increasing recycling rate, integrating energy from waste into household and reducing consumption of resources and waste generation. A sustainability assessment through economic cost-benefit analysis, environmental LCA and assessment of the social dimensions was conducted to gain a holistic view of the system performance. This method informs decision-making by making the trade-offs and synergies between these dimensions clearer.

Under the current "waste-and-energy" practices, switching from conventional grid electricity to solar PV renewable electricity can result in greater environmental impact savings compared to increasing household recycling rate, though combining both approaches would certainly offer the greatest advantage. The best performing scenario in terms of lowest environmental impact demonstrated in this study combines switching to solar PV, increasing recycling rate and using electricity generated from waste, however this strategy could take a longer period to implement. Reducing consumption of resources and waste generation which merely relies on social behavioural change could be difficult in achieving significant impact if policy and motivation are not in place. In principle, the paradigm shift for the uptake of renewable technology and increasing recycling rate is normally driven by the monetary benefits either through cost reduction or income generation from government incentives. 
1 Reducing damage to human health should also be considered as one of the main criteria within the social dimension.

3 A greater technology adoption, behavioural change and a more supportive policy instrument are 4 essential for realising transformational changes in resource utilisation and management. A household perspective using the appropriate model for dealing with energy and waste is important for enhancing economic and environmental performance at both household and national levels. Uptake of solar PV and recycling could benefit from stronger policy support. For solar PV, this could include additional incentives for generating extra electricity which can be sold to the grid. For waste, the current fixed rate council tax means that households are charged the same rate regardless of the amount of waste thrown. The impact of introducing either a reward or penalty ("carrots or sticks") scheme for waste 11 depends strongly on the local context and more evidence is needed before introducing such schemes. 12 Education and community participation are important aspects in driving and promoting systems thinking in households.

14 Some of the practical strategies that can be introduced to the UK households based on the analysis of different models are as follows:

- If only the energy domain is considered and recognising that large magnitude of energy demand reduction (i.e. $>50 \%$ ) in household may not be practically achievable, then the most promising strategy is to switch household energy supply system fully into renewable solar PV electricity.

- If only the waste domain is considered and recognising that large magnitude of waste generation reduction in household (i.e. $>50 \%$ ) may not be practically achievable, then the most promising strategy is to promote higher recycling rate.

- If both energy and waste domains are considered, then switching into solar PV energy, increasing recycling rate and using electricity generated from waste simultaneously are the most promising strategies to achieve greater economic, environmental and social benefits.

In conclusion, examining the household energy and waste using a whole system approach enables systematic scoping of resource recovery opportunities and provide a more sustainable solution to urban planning. The transformation would not be straightforward since it involves technological transformation and behavioural change which also requires changes in policies and markets. 
This work was supported by the Natural Environment Research Council (NE/R012938/1) through the UKRI/NERC Industrial Innovation Fellowship Programme, and by the Royal Academy of Engineering under the Research Fellowship scheme.

\section{References}

[1] Committee on Climate Change. 2019. Net Zero: The UK's contribution to stopping global warming. Available from: https:/www.theccc.org.uk/wp-content/uploads/2019/05/Net-Zero-TheUKs-contribution-to-stopping-global-warming.pdf [cited 11 October 2019].
[2] United
Nations.
2015. Paris
Agreement.
Available from: https://unfccc.int/sites/default/files/english_paris_agreement.pdf [cited 11 October 2019].

[3] Intergovernmental Panel on Climate Change (IPCC). 2018. Special Report: Global Warming of $1.5^{\circ} \mathrm{C}$. Available from: https://www.ipcc.ch/sr15/ [cited 11 October 2019].

[4] Department for Business, Energy and Industrial Strategy (BEIS). 2019. 2018 UK Greenhouse Gas Emissions, Provisional Figures. Available from: https://assets.publishing.service.gov.uk/government/uploads/system/uploads/attachment data/file/7 90626/2018-provisional-emissions-statistics-report.pdf [cited 7 October 2019].

[5] Committee on Climate Change. 2016. UK Climate Action Following the Paris Agreement. Available from: https:/www.theccc.org.uk/wp-content/uploads/2016/10/UK-climate-actionfollowing-the-Paris-Agreement-Committee-on-Climate-Change-October-2016.pdf [cited 12 October 2019].

[6] Deep Decarbonization Pathways Project (DDPP). 2015. Pathways to Deep Decarbonization. Available from: http://deepdecarbonization.org/wpcontent/uploads/2016/03/DDPP_2015_REPORT.pdf [cited 12 October 2019].

[7] Department for Environment, Food \& Rural Affairs (DEFRA). 2018. Digest of waste and resource statistics, 2018 edition. Available from: https://www.gov.uk/government/statistics/digestof-waste-and-resource-statistics-2018-edition [cited 23 September 2019].

[8] European Commission. 2008. Directive 2008/98/EC of the European Parliament and of the Council of 19 November 2008 on waste and repealing certain Directives. Available from: http://eurlex.europa.eu/legal-content/EN/TXT/?uri=celex\%3A32008L0098 [cited 23 November 2019]. [9] Department for Environment, Food \& Rural Affairs (Defra) and Government Statistical Service. 2019. UK Statistics on Waste. Available from: https://assets.publishing.service.gov.uk/government/uploads/system/uploads/attachment_data/file/7 84263/UK_Statistics_on_Waste_statistical_notice_March_2019_rev_FINAL.pdf [cited 25 September 2019].

[10] Bosch, O.J.H., King, C.A., Herbohn, J.L., Russell, I.W., Smith, C.S., 2007. Getting the big picture in natural resource management - systems thinking as 'method' for scientists, policy makers and other stakeholders. Systems Research and Behavioral Science. 24(2): 217-232.

[11] Ng, K.S., Yang, A., Yakovleva, N., 2019. Sustainable waste management through synergistic utilisation of commercial and domestic organic waste for efficient resource recovery and valorisation in the UK. Journal of Cleaner Production. 227: 248-262.

[12] Su, Y., Zhou, Y., Tan, M., 2020. An interval optimization strategy of household multi-energy system considering tolerance degree and integrated demand response. Applied Energy. 260: 114144. 
[13] Yu, H., Zhang, C., Deng, Z., Bian, H., Sun, C., Jia, C., 2018. Economic optimization for configuration and sizing of micro integrated energy systems. Journal of Modern Power Systems and Clean Energy. 6(2): 330-341.

4 [14] Mayer, M.J., Szilágyi, A., Gróf, G., 2020. Environmental and economic multi-objective optimization of a household level hybrid renewable energy system by genetic algorithm. Applied Energy. 269: 115058.

[15] Üçtuğ, F.G. and Azapagic, A., 2018. Environmental impacts of small-scale hybrid energy systems: Coupling solar photovoltaics and lithium-ion batteries. Science of The Total Environment. 643: 1579-1589.

[16] Golmohamadi, H., Keypour, R., Bak-Jensen, B., Radhakrishna Pillai, J., 2019. Optimization of household energy consumption towards day-ahead retail electricity price in home energy management systems. Sustainable Cities and Society. 47: 101468.

[17] Vogt Gwerder, Y., Marques, P., Dias, L.C., Freire, F., 2019. Life beyond the grid: A LifeCycle Sustainability Assessment of household energy needs. Applied Energy. 255: 113881.

[18] Jeswani, H.K. and Azapagic, A., 2016. Assessing the environmental sustainability of energy recovery from municipal solid waste in the UK. Waste Management. 50: 346-363.

[19] Jamasb, T. and Nepal, R., 2010. Issues and options in waste management: A social costbenefit analysis of waste-to-energy in the UK. Resources, Conservation and Recycling. 54(12): 13411352.

Ellen MacArthur Foundation. 2014. Towards the Circular Economy: Accelerating the Scaleup Across Global Supply Chains. Available from: http://www3.weforum.org/docs/WEF ENV TowardsCircularEconomy Report 2014.pdf [cited 15 October 2019].

[21] United Nations. 2015. Transforming Our World: the 2030 Agenda for Sustainable Development. Available from: https://www.un.org/sustainabledevelopment/developmentagenda/. [cited 21 November 2019].

[22] Brunner, P.H. and Rechberger, H., 2004. Practical Handbook of Material Flow Analysis. CRC Press, Florida.

[23] William McDonough \& Partners. 1992. The Hannover Principles: Design for Sustainability. Available from: https://www.mcdonough.com/wp-content/uploads/2013/03/Hannover-Principles1992.pdf [cited 15 October 2019].

[24] Santoyo-Castelazo, E. and Azapagic, A., 2014. Sustainability assessment of energy systems: integrating environmental, economic and social aspects. Journal of Cleaner Production. 80: 119-138. [25] Iacovidou, E., Busch, J., Hahladakis, J.N., Baxter, H., Ng, K.S., Herbert, B.M.J., 2017. A Parameter Selection Framework for Sustainability Assessment. Sustainability. 9(9): 1497.

[26] Sadhukhan, J., Ng, K.S., Martinez-Hernandez, E., 2014. Biorefineries and Chemical Processes: Design, Integration and Sustainability Analysis. . Wiley, Chichester.

[27] International Organization for Standardization (ISO). 2006. ISO 14040:2006 Environmental management — Life cycle assessment - Principles and framework. Available from: https://www.iso.org/standard/37456.html [cited 10 October 2019].

[28] British Standards Institution. 2011. PAS 2050:2011: Specification for the Assessment of the Life Cycle Greenhouse Gas Emissions of Goods and Services. Available from: http://shop.bsigroup.com/upload/shop/download/pas/pas2050.pdf [cited 16 October 2019].

[29] World Resources Institute and World Business Council for Sustainable Development. 2004. The Greenhouse Gas Protocol: A Corporate Accounting and Reporting Standard. Available from: http://pdf.wri.org/ghg_protocol_2004.pdf [cited 16 October 2019].

[30] Huijbregts, M.A.J., Steinmann, Z.J.N., Elshout, P.M.F., Stam, G., Verones, F., Vieira, M., Zijp, M., Hollander, A., Zelm., R.v., 2017. ReCiPe2016: a harmonized life cycle impact assessment method at midpoint and endpoint level. Issue 2/2017. The International Journal of Life Cycle Assessment. 
[31] Iacovidou, E., Velis, C.A., Purnell, P., Zwirner, O., Brown, A., Hahladakis, J., MillwardHopkins, J., Williams, P.T., 2017. Metrics for optimising the multi-dimensional value of resources recovered from waste in a circular economy: A critical review. Journal of Cleaner Production. 166: 910-938.

[32] Department for Business, Energy \& Industrial Strategy (BEIS). 2018. Energy Consumption in the UK. Available from: https://www.gov.uk/government/statistics/energy-consumption-in-the-uk [cited 2 November 2018].

8 [33] Department of Energy \& Climate Change (DECC). 2014. Household electricity survey [cited 2 November 2018].

[34] Department for Business, Energy \& Industrial Strategy (BEIS). 2019. Quarterly Energy Prices, June 2019. Available from: https://www.gov.uk/government/statistics/quarterly-energy-prices-june2019 [cited 19 September 2019].

[35] Ofgem. 2017. Typical Domestic Consumption Values. Available from: https://www.ofgem.gov.uk/gas/retail-market/monitoring-data-and-statistics/typical-domesticconsumption-values. [cited 19 September 2019]

[36] Ofgem. 2019. Feed-In Tariff (FIT) rates. Available from: https://www.ofgem.gov.uk/environmental-programmes/fit/fit-tariff-rates. [cited 4 November 2019] [37] Department for Business, Energy \& Industrial Strategy (BEIS). 2019. Solar photovoltaic (PV) cost data. Available from: https://www.gov.uk/government/statistics/solar-pv-cost-data [cited 4 November 2019].

[38] Veolia. 2013. VALORGAS: Evaluation of food-excluded residual waste streams and impact on energy balance. EU FP7 Technical Report (D2.6). Available from: http://www.valorgas.soton.ac.uk/deliverables.htm [cited 23 September 2019].

[39] Letsrecycle.com. 2018. The letsrecycle.com prices section. Available from: https://www.letsrecycle.com/prices/. [cited 28 November 2018]

[40] Oxfordshire County Council. 2019. Council funding and spending. Available from: https://www.oxfordshire.gov.uk/council/about-your-council/council-tax-and-finance/councilfunding-and-spending. [cited 4 November 2019]

[41] Department of Energy \& Climate Change (DECC). 2010. National Renewable Energy Action Plan for the United Kingdom Available from: https:/www.gov.uk/government/publications/nationalrenewable-energy-action-plan [cited 12 May 2020].

[42] European Commission. 2009. Directive 2009/28/EC of the European Parliament and of the Council of 23 April 2009 on the promotion of the use of energy from renewable sources and amending and subsequently repealing Directives 2001/77/EC and 2003/30/EC, Official Journal of the European Union. Available from: https://eur-lex.europa.eu/legalcontent/EN/TXT/PDF/?uri=CELEX:32009L0028\&from=EN [cited 12 May 2020].

[43] European Commission. 2019. Assessment of the draft National Energy and Climate Plan of the United Kingdom, Brussels, 18.6.2019, $\operatorname{SWD}(2019) 279$ final. Available from: https://ec.europa.eu/energy/sites/ener/files/documents/uk_swd_en.pdf [cited 12 May 2020].

[44] Department for Business, Energy \& Industrial Strategy (BEIS). 2019. The UK's draft integrated National Energy and Climate Plan. Available from: https://www.gov.uk/government/publications/uk-national-energy-and-climate-plan-necp [cited 12 May 2020].

[45] European Commission. 1999. Council Directive 1999/31/EC of 26 April 1999 on the landfill of waste. Available from: http://eur-lex.europa.eu/legal-content/EN/ALL/?uri=CELEX:31999L0031 [cited 23 November 2019].

[46] Smith, L. and Bolton, P. House of Commons Library. 2018. Household recycling in the UK. Briefing paper. Number 7285. Available from: https://researchbriefings.parliament.uk/ResearchBriefing/Summary/CBP-7285\#fullreport [cited 25 September 2019]. 
[47] SUEZ. 2015. At this rate - exploring England's recycling challenges. Available from: https://www.suez.co.uk/en-gb/news/list-of-publications [cited 7 October 2019].

3 [48] Greenmatch. 2019. 4kW Solar Panel System: Things to Know before Buying a $4 \mathrm{~kW}$ Solar 4 Panel System. Available from: https://www.greenmatch.co.uk/solar-energy/solar-system/4kw-solar5 panel-system. [cited 4 November 2019]

6 [49] The Ecoexperts. 2019. Solar Panel Output: How Much Electricity Do They Produce? ; Available from: https://www.theecoexperts.co.uk/solar-panels/electricity-poweroutput\#\#targetText=These $\% 20$ can $\% 20$ range $\% 20 \mathrm{in} \% 20$ size,system $\% 20(250 \% 20 \mathrm{x} \% 204)$. [cited 4 November 2019]

10 [50] Oxfordshire County Council. 2012. 2011 Census data table KS105EW - Household 11 composition. Available from: http://insight.oxfordshire.gov.uk/cms/2011-census-data-table12 ks105ew-household-composition. [cited 4 November 2019]

13 [51] Office for National Statistics. 2017. Families and Households. Available from: 14 https://www.ons.gov.uk/peoplepopulationandcommunity/birthsdeathsandmarriages/families/bulletin 15 s/familiesandhouseholds/2017 [cited 23 September 2019].

16 [52] YouGov and ClientEarth. 2018. ClientEarth's Climate Snapshot: A survey of UK attitudes towards climate change and its impacts. Available from: https://www.documents.clientearth.org/wpcontent/uploads/library/2018-08-20-clientearths-climate-snapshot-coll-en.pdf [cited 7 November 2019].

20 [53] Department for Business, Energy \& Industrial Strategy (BEIS). 2019. Solar photovoltaics 21 deployment: October 2019. Available from: https://www.gov.uk/government/statistics/solar22 photovoltaics-deployment [cited 7 November 2019]. [54] Balcombe, P., Rigby, D., Azapagic, A., 2013. Motivations and barriers associated with adopting microgeneration energy technologies in the UK. Renewable and Sustainable Energy Reviews. 22: 655-666.

[55] Greater London Authority. 2011. Waste not, want not: A review of why recycling rates vary across London.

Available from: https://www.london.gov.uk/sites/default/files/gla migrate files destination/Recycling $\% 20$ Rates $\% 2$ 0Final\%20Report.pdf [cited 7 November 2011]. 